Atmos. Chem. Phys., 19, 13289-13308, 2019

https://doi.org/10.5194/acp-19-13289-2019

(C) Author(s) 2019. This work is distributed under

the Creative Commons Attribution 4.0 License.

\title{
Semi-quantitative understanding of source contribution to nitrous acid (HONO) based on 1 year of continuous observation at the SORPES station in eastern China
}

\author{
Yuliang Liu ${ }^{1,2}$, Wei Nie ${ }^{1,2}$, Zheng Xu ${ }^{1,2}$, Tianyi Wang ${ }^{1,2}$, Ruoxian Wang ${ }^{1,2}$, Yuanyuan $\mathbf{L i}^{1,2}$, Lei Wang ${ }^{1,2}$, \\ Xuguang Chi ${ }^{1,2}$, and Aijun Ding ${ }^{1,2}$ \\ ${ }^{1}$ Joint International Research Laboratory of Atmospheric and Earth System Sciences, School of Atmospheric Sciences, \\ Nanjing University, Nanjing, Jiangsu Province, 210023, China \\ ${ }^{2}$ Jiangsu Provincial Collaborative Innovation Center of Climate Change, Nanjing, Jiangsu Province, 210023, China
}

Correspondence: Wei Nie (niewei@nju.edu.cn) and Zheng Xu (zheng.xu@nju.edu.cn)

Received: 6 March 2019 - Discussion started: 25 April 2019

Revised: 8 September 2019 - Accepted: 10 September 2019 - Published: 28 October 2019

\begin{abstract}
Nitrous acid (HONO), an important precursor of the hydroxyl radical $(\mathrm{OH})$, has long been recognized as of significance to atmospheric chemistry, but its sources are still debated. In this study, we conducted continuous measurement of HONO from November 2017 to November 2018 at the SORPES station in Nanjing of eastern China. The yearly average mixing ratio of observed $\mathrm{HONO}$ was $0.69 \pm 0.58 \mathrm{ppb}$, showing a larger contribution to $\mathrm{OH}$ relative to ozone with a mean $\mathrm{OH}$ production rate of $1.16 \mathrm{pph}^{-1}$. To estimate the effect of combustion emissions of HONO, the emitted ratios of HONO to $\mathrm{NO}_{x}$ were derived from 55 fresh plumes $\left(\mathrm{NO} / \mathrm{NO}_{x}>0.85\right)$, with a mean value of $0.79 \%$. During the nighttime, the chemistry of HONO was found to depend on $\mathrm{RH}$, and heterogeneous reaction of $\mathrm{NO}_{2}$ on an aerosol surface was presumably responsible for HONO production. The average nighttime $\mathrm{NO}_{2}$-to-HONO conversion frequency $\left(C_{\mathrm{HONO}}\right)$ was determined to be $0.0055 \pm 0.0032 \mathrm{~h}^{-1}$ from 137 HONO formation cases. The missing source of HONO around noontime seemed to be photo-induced, with an average $P_{\text {unknown }}$ of $1.04 \mathrm{ppb} \mathrm{h}^{-1}$, based on a semi-quantitative HONO budget analysis. An over-determined system of equations was applied to obtain the monthly variations in nocturnal HONO sources. Besides the burning-emitted HONO (accounting for about $23 \%$ of the total concentration), the contribution of HONO formed heterogeneously on ground surfaces to measured HONO was an approximately constant proportion of $36 \%$ throughout the year. The soil emission revealed clear seasonal variation and contributed up to $40 \%$ of observed HONO in July and August. A higher propensity
\end{abstract}

for generating $\mathrm{HONO}$ on aerosol surfaces occurred in severe hazes (accounting for $40 \%$ of the total concentration in January). Our results highlight ever-changing contributions of HONO sources and encourage more long-term observations to evaluate the contributions from varied sources.

\section{Introduction}

Nitrous acid (HONO) is a vital constituent of nitrogen cycle in the atmosphere, first observed in the field by Perner and Platt (1979). The concentrations of HONO varied from dozens of parts per trillion in remote regions (Villena et al., 2011b; Meusel et al., 2016) to several ppb in polluted urban regions (Yu et al., 2009; Tong et al., 2015). The photolysis of HONO (R1) has been long standing as a momentous source of the hydroxyl radicals $(\mathrm{OH})$, especially during the early morning, when other $\mathrm{OH}$ sources are minor (Platt et al., 1980; Alicke, 2002, 2003). Even during the daytime, recent studies have recognized the photolysis of HONO as a potentially stronger contributor to daytime $\mathrm{OH}$ radicals than that of $\mathrm{O}_{3}$ (Kleffmann, 2005; Elshorbany et al., 2009; Li et al., 2018). Meanwhile, HONO has been found to affect adversely human heath (Jarvis et al., 2005; Sleiman et al., 2010).

Although the significance of HONO has been given much weight, the sources of ambient $\mathrm{HONO}$ are complicated and have been debated for decades. HONO can be emitted from combustion, including vehicle exhaust, industrial exhaust and biomass burning (Table 1). Tunnel experiments with tests 
for different engine types have determined an emission ratio of $\mathrm{HONO} / \mathrm{NO}_{x}$ for traffic sources, ranging from $0.3 \%$ to $0.8 \%$ (Kirchstetter et al., 1996; Kurtenbach et al., 2001). The release from soil nitrite through acidification reaction and partitioning is considered to be another primary source of atmospheric HONO (Su et al., 2011). Soil nitrite can come from biological nitrification and denitrification processes (Canfield et al., 2010; Oswald et al., 2013) or be enriched via reactive uptake of $\mathrm{HONO}$ from the atmosphere (VandenBoer et al., 2014a, b). In addition to direct emissions, the vast majority of HONO is produced chemically. The recombination of $\mathrm{NO}$ and $\mathrm{OH}(\mathrm{R} 3)$ is the main homogeneous reaction for supplying HONO (Pagsberg et al., 1997; Atkinson, 2000), whose contribution may be significant under conditions of sufficient reactants at daytime. During the nighttime, with low $\mathrm{OH}$ concentrations, other larger sources, i.e., heterogeneous reactions of $\mathrm{NO}_{2}$ on various surfaces, are required to explain elevated mixing levels of HONO. Laboratory studies indicate that $\mathrm{NO}_{2}$ can be converted to $\mathrm{HONO}$ on humid surfaces (Reaction R4), being first order in $\mathrm{NO}_{2}$ and depending on various parameters including the gas-phase $\mathrm{NO}_{2}$ concentration, the surface water content, and the surface area density (Kleffmann et al., 1998; Finlayson-Pitts et al., 2003). Besides, the heterogeneous reduction of $\mathrm{NO}_{2}$ with surface organics (R5) is proposed to be another effective pathway to generate HONO (Ammann et al., 1998, 2005; Aubin and Abbatt, 2007), observed in freshly emitted plumes with high concentrations of $\mathrm{NO}_{x}$ (Xu et al., 2015). Notably this reaction rate is drastically reduced after the first few seconds due to consumption of the reactive surfaces (Kalberer et al., 1999; Kleffmann et al., 1999), but this reaction could be strongly enhanced by light on photo-activated surfaces (George et al., 2005; Stemmler et al., 2006, 2007). During the daytime, heterogeneous HONO formation from the photolysis of adsorbed nitric acid $\left(\mathrm{HNO}_{3}\right)$ and particulate nitrate $\left(\mathrm{NO}_{3}^{-}\right)$at $\mathrm{UV}$ wavelengths has been found in experiments and observations (Zhou et al., 2003, 2011; Ye et al., 2016, 2017). Heterogeneous processes are typically considered the main sources of HONO in many regions, yet are the most poorly understood. For $\mathrm{NO}_{2}$ conversion to $\mathrm{HONO}$ on surfaces (R4, R5), the uptake coefficients of $\mathrm{NO}_{2}$ derived from different experiments vary from $10^{-9}$ to $10^{-2}$ (Ammann et al., 1998; Kirchner et al., 2000; Underwood et al., 2001; Aubin and Abbatt, 2007; Zhou et al., 2015). The key step to determine the uptake of $\mathrm{NO}_{2}$ or the reaction rate is still ill-defined, and we are also not certain whether and how the ambient natural surfaces can be reactivated by radiation. Furthermore, it has become a main concern to compare the contributions of ground and aerosol surfaces to HONO formation. It is so far not well explained for the observed HONO, especially during daytime. Large unknown sources of HONO have been identified by many studies (Su et al., 2008b; Sörgel et al., 2011; Michoud et al., 2014; Lee et al., 2016).

Benefitting from more and more studies, particularly the observations under different environments (Lammel and
Cape, 1996; Li et al., 2012), understanding of HONO chemistry in the atmosphere has been greatly improved during the last decade. However, most HONO observations were shortterm campaigns, with studies ranging from several weeks to several months. For example, Reisinger (2000) found a linear correlation between the $\mathrm{HONO} / \mathrm{NO}_{2}$ ratio and aerosol surface density in the polluted winter atmosphere, Nie et al. (2015) showed the influence of biomass burning plumes on HONO chemistry, according to observed data during late April-June 2012, while Wong et al. (2011) believed that $\mathrm{NO}_{2}$-to-HONO conversion on the ground was the dominant source of $\mathrm{HONO}$ by analyzing vertical profiles from $15 \mathrm{Au}-$ gust to 20 September 2006. Moreover, a perspective that HONO from soil emission explained the strength and diurnal variations of the missing source has been presented by Su et al. (2011) based on data measured from 23 to 30 October 2004. In case the HONO sources exhibit temporal variability, especially seasonal differences, it is challenging to draw a full picture on the basis of these short-term observations. More than a year of continuous observation is needed, yet is rather limited.

The Yangtze River delta (YRD) is one of the most developed regions in eastern China. Rapid urbanization and industrialization have induced severe air pollution over the last 3 decades, particularly high concentrations of reactive nitrogen (Richter et al., 2005; Rohde and Muller, 2015), including HONO (Wang et al., 2013; Nie et al., 2015). In this study, we conducted HONO observations continuously from November 2017 to November 2018 at the Station for Observing Regional Processes and the Earth System (SORPES) located in the western part of the YRD, a place that can be influenced by air masses from different source regions of anthropogenic emissions, biomass burning, dust and biogenic emissions (Ding et al., 2013, 2016). Our 1-year observation showed well-defined diurnal patterns and obvious seasonal variations of HONO concentrations at relatively high levels. We discussed the potential mechanism of HONO production based upon semiquantitative analysis and correlation studies and paid special attention to changes in major sources of HONO during different seasons.

\section{Methodology}

\subsection{Study site and instrumentation}

Continuous observation was conducted at the SORPES station at the Xianlin Campus of Nanjing University $\left(118^{\circ} 57^{\prime} \mathrm{E}\right.$, $32^{\circ} 07^{\prime} \mathrm{N}$ ), located in the northeastern suburb of Nanjing, China, from November 2017 to November 2018 (Supplement Fig. S1). The easterly prevailing wind and synoptic condition make it a representative background site of Nanjing and a regional downwind site of the city cluster in the YRD region. Detailed descriptions for the station can be found in previous studies (Ding et al., 2013, 2016). 
Table 1. Sources and sinks for HONO in the troposphere.

\begin{tabular}{|c|c|c|c|}
\hline Budget & Occurrence & Pathways & Abbr. \\
\hline \multirow[t]{3}{*}{ Sinks } & Only daytime & $\mathrm{HONO}+h v \stackrel{320-400 \mathrm{~nm}}{\longrightarrow} \mathrm{OH}+\mathrm{NO}$ & (R1) \\
\hline & Mainly daytime & $\mathrm{HONO}+\mathrm{OH} \rightarrow \mathrm{NO}_{2}+\mathrm{H}_{2} \mathrm{O}$ & (R2) \\
\hline & All day & Deposition/heterogeneous loss on aerosol & - \\
\hline \multirow[t]{6}{*}{ Sources } & Mainly daytime & $\mathrm{NO}+\mathrm{OH} \stackrel{\mathrm{M}}{\longrightarrow} \mathrm{HONO}$ & (R3) \\
\hline & Mainly nighttime & $2 \mathrm{NO}_{2(\mathrm{~g})}+\mathrm{H}_{2} \mathrm{O}_{(\mathrm{ads})} \stackrel{\text { surf }}{\longrightarrow} \mathrm{HONO}_{(\mathrm{g})}+\mathrm{HNO}_{3(\mathrm{ads})}$ & (R4) \\
\hline & Mainly daytime & $\mathrm{NO}_{2(\mathrm{~g})}+\mathrm{HC}_{\mathrm{red}} \stackrel{\text { surf }}{\longrightarrow} \mathrm{HONO}_{(\mathrm{g})}+\mathrm{HC}_{\mathrm{ox}}$ & (R5) \\
\hline & Only daytime & $\mathrm{HNO}_{3} / \mathrm{NO}_{3}^{-}+\mathrm{h} v \stackrel{\text { surf }}{\longrightarrow} \mathrm{HONO} / \mathrm{NO}_{2}^{-}+\mathrm{O}$ & (R6) \\
\hline & All day & Release of soil nitrite & - \\
\hline & All day & Combustion emission (fossil and biomass) & - \\
\hline
\end{tabular}

HONO was measured with a commercial long-path absorption photometer instrument (QUMA, model LOPAP-03). The ambient air was sampled in two similar temperaturecontrolled stripping coils in series using a mixture reagent of $100 \mathrm{~g}$ sulfanilamide and $1 \mathrm{~L} \mathrm{HCl}(37 \%$ volume fraction) in $9 \mathrm{~L}$ pure water. In the first stripping coil, all of the $\mathrm{HONO}$ and a fraction of interfering substances were absorbed into solution, and the remaining interfering species $\left(\mathrm{NO}_{2}, \mathrm{HNO}_{3}, \mathrm{HO}_{2} \mathrm{NO}_{2}, \mathrm{PAN}\right.$, etc.) were absorbed in the second stripping coil. After adding a reagent of $0.8 \mathrm{~g} \mathrm{~N}$ naphtylethylendiamine-dihydrochloride in $8 \mathrm{~L}$ pure water, colored azo dye was formed in the solutions from two stripping coils, which were then separately detected via long-path absorption in special Teflon tubing. To minimize the measurement interferences, the real HONO signal was the difference between the signals in the two channels. Further details can be found in Heland et al. (2001) and Kleffmann et al. (2006). To correct for the small drifts in the instrument's baseline, the compressed air was sampled every $12 \mathrm{~h}$ (flow rate: $1.0 \mathrm{~L} \mathrm{~min}^{-1}$ ) to make zero measurement. A span check was made using $0.04 \mathrm{mg} \mathrm{m}^{-3}$ nitrite $\left(\mathrm{NO}_{2}^{-}\right)$solution every 2 weeks with a flow rate of $0.28 \mathrm{~mL} \mathrm{~min}^{-1}$. The time resolution, detection limit, and accuracy of the measurement were $5 \mathrm{~min}, 10 \mathrm{pptv}$, and $10 \%$, respectively.

The $\mathrm{NO}$ and $\mathrm{NO}_{2}$ levels were measured using a chemiluminescence instrument (TEI, model 42i) coupled with a highly selective photolytic converter (Droplet Measurement Technologies, model BLC), and the analyzer had a detection limit of $50 \mathrm{pptv}$ for an integration time of $5 \mathrm{~min}$, with precision of $4 \%$ and an uncertainty of $10 \%$ (Xu et al., 2013). Ozone and $\mathrm{CO}$ were measured continuously using ThermoFisher Scientific TEI 49i and TEI 48i, respectively. The fine particle mass concentration $\left(\mathrm{PM}_{2.5}\right)$ was continuously measured with a combined technique of light scattering photometry and beta radiation attenuation (Thermo Scientific SHARP Monitor Model 5030). Water-soluble aerosol ions $\left(\mathrm{NO}_{3}^{-}, \mathrm{SO}_{4}^{2-}, \mathrm{NH}_{4}^{+}\right.$, etc.) and ammonia $\left(\mathrm{NH}_{3}\right)$ were measured by a Monitor for Aerosols and Gases in ambient Air (designed and manufactured by Applikon Analytical B.V., the Netherlands) with a $\mathrm{PM}_{2.5}$ cyclone inlet, at a time resolution of $1 \mathrm{~h}$. The size distribution of submicron particles $(6-820 \mathrm{~nm})$ is measured with a DMPS (differential mobility particle sizer) constructed at the University of Helsinki in Finland. Meteorological measurements including relative humidity $(\mathrm{RH})$, wind speed, wind direction, and air temperature were recorded by Automatic Weather Station (CAMPEEL co., AG1000). UVB total radiation was measured by a UVB radiometer (UVS-B-T UV Radiometer, KIPP \& ZONEN).

\subsection{TUV model and OH estimate}

The Tropospheric Ultraviolet and Visible (TUV) radiation model (https://www2.acom.ucar.edu/modeling/ tropospheric-ultraviolet-and-visible-tuv-radiation-model, last access: 10 October 2019) was adopted to compute the photolysis frequencies, which is most probably accurate in clean and cloudless days. The pivotal parameters of this model were inputted as follows: the ozone density was measured by the Ozone Monitoring Instrument (OMI); the typical single scattering albedo (SSA) and Ångström exponent (Alpha) were 0.93 and 1.04 (Shen et al., 2018). The mean value of optical depth (AOD) at $550 \mathrm{~nm}$ was 0.64 , derived following an empirical relationship with $\mathrm{PM}_{2.5}$ in Nanjing (Shao et al., 2017). To reduce the error of the model, we used observed UVB to correct simulated results $\left(J_{\bmod }\right)$ by Eq. (1).

$J=\frac{\mathrm{UVB}_{\mathrm{obs}}}{\mathrm{UVB}_{\mathrm{mod}}} J_{\mathrm{mod}}$

The daytime $\mathrm{OH}$ concentration was calculated by applying the empirical model (Eq. 2) proposed by Rohrer and Berresheim (2006), based on strong nearly linear correlations of measured $\mathrm{OH}$ concentrations with simultaneously observed $\mathrm{J}\left(\mathrm{O}^{1} \mathrm{D}\right)$. The coefficient $a$ reflects the average influence of reactants (e.g., $\mathrm{NO}_{x}$, VOCs, ozone, $\mathrm{H}_{2} \mathrm{O}$ ) on $\mathrm{OH}$ at the selected place for research; the exponent $b$ represents the combined effects of all photolytic processes on $\mathrm{OH}$, for 
example, $\mathrm{J}\left(\mathrm{O}^{1} \mathrm{D}\right), \mathrm{J}\left(\mathrm{NO}_{2}\right), \mathrm{J}(\mathrm{HONO})$, and $\mathrm{J}(\mathrm{HCHO})$; and the parameter $c$ counts the light-independent $\mathrm{OH}$ sources. The values of coefficients $a, b$ and $c$ in Eq. (2) are adopted from the $\mathrm{OH}$ studies in the Pearl River delta (PRD) and Beijing, China (Rohrer et al., 2014; Tan et al., 2017, 2018). By summarizing the coefficients $a, b$, and $c$ in different $\mathrm{OH}$ observation campaigns (Table $\mathrm{S} 1$ in the Supplement), especially the almost equal slope of the $\mathrm{OH}-\mathrm{J}\left(\mathrm{O}^{1} \mathrm{D}\right)$ relation for different locations and seasons in the polluted areas of China, we can make assumptions that the comprehensive impact of reactants (e.g., $\mathrm{NO}_{x}$ and VOCs) on $\mathrm{OH}$ cannot compete with that of UV light to $\mathrm{OH}$, and the chemical environments of $\mathrm{OH}$ are similar. This suggests that it can be a reasonable way to derive $\mathrm{OH}$ by using Eq. (2) in our study, and the error of derived $\mathrm{OH}$ radicals has been assessed as not subverting the relative conclusions in this study (Fig. S1a and d). The calculated $\mathrm{OH}$ concentrations around noon $\left.\left(\mathrm{J}\left(\mathrm{O}^{1} \mathrm{D}\right)\right)>1 \times 10^{-5} \mathrm{~s}^{-1}\right)$ were in the range of $0.46-2.0 \times 10^{7} \mathrm{~cm}^{-3}$, comparable to observations in Chinese urban or suburban atmospheres ( $\mathrm{Lu}$ et al., 2012, 2013).

$$
\begin{aligned}
& {[\mathrm{OH}]=a \times\left(\mathrm{J}\left(\mathrm{O}^{1} \mathrm{D}\right) / 10^{-5} \mathrm{~s}^{-1}\right)^{b}+c} \\
& a=4.2 \times 10^{6} \mathrm{~cm}^{-3}, b=1 \\
& c=1.0 \times 10^{6} \mathrm{~cm}^{-3} \text { in summer } \\
& c=0.6 \times 10^{6} \mathrm{~cm}^{-3} \text { in spring, autumn } \\
& c=0.2 \times 10^{6} \mathrm{~cm}^{-3} \text { in winter }
\end{aligned}
$$

\section{Results}

\subsection{Observation overview}

We carried out continuous measurements for $\mathrm{HONO}$ at the SORPES station in the northeastern suburb of Nanjing from November 2017 to November 2018 with a mean measured ambient HONO mixing level of $0.69 \pm 0.58 \mathrm{ppb}$ (Fig. S2), within the range of those in the center or vicinity of megacities (Table 2). Figure 1 shows the seasonal pattern of HONO and related parameters. The highest concentration of HONO is found in winter ( $1.04 \pm 0.75 \mathrm{ppb})$, followed by spring $(0.68 \pm 0.48 \mathrm{ppb})$, autumn $(0.66 \pm 0.53 \mathrm{ppb})$ and summer $(0.45 \pm 0.37 \mathrm{ppb})$. Such seasonal variations in Nanjing are aligned with that in Beijing (Hendrick et al., 2014) and are somewhat similar to those in Jinan (Li et al., 2018), where the highest levels occurred in winter and the lowest levels occurred in autumn, but these variations are different from those in Hongkong (Xu et al., 2015), where the highest and lowest values of HONO appeared in autumn and spring, respectively. The important point is that the seasonality of $\mathrm{HONO}$ coincides with that of $\mathrm{NO}_{x}\left(\right.$ or $\left.\mathrm{NO}_{2}\right)$, which is believed to be the main precursor of HONO in current studies.

The HONO-to- $\mathrm{NO}_{x}$ ratio or the HONO-to- $\mathrm{NO}_{2}$ ratio has been used extensively in previous studies to characterize the
HONO levels and to indicate the extent of heterogeneous conversion of $\mathrm{NO}_{2}$ to $\mathrm{HONO}$, since it is less influenced by convection or transport processes than the individual concentration (Lammel and Cape, 1996; Stutz et al., 2002). When a large proportion of HONO comes from direct emissions, the value of $\mathrm{HONO} / \mathrm{NO}_{2}$ usually becomes larger, falsely implying the strong formation of $\mathrm{HONO}$ from $\mathrm{NO}_{2}$. However, the freshly emitted air masses generally have the lowest $\mathrm{HONO} / \mathrm{NO}_{x}$ ratio, meaning that $\mathrm{HONO} / \mathrm{NO}_{x}$ behaves better than $\mathrm{HONO} / \mathrm{NO}_{2}$ in a way. As shown in Fig. $1 \mathrm{~b}$, the low value of $\mathrm{HONO} / \mathrm{NO}_{x}$ in winter is attributed to heavy emissions because we see high mixing ratios of NO during this cold season (Fig. 1c); the reasons for the two peaks of $\mathrm{HONO} / \mathrm{NO}_{x}$ in spring and summer will be discussed in Sects. 3.3, 3.4 and 4.

All daily changes in HONO concentration in different seasons closely resemble a cycle where HONO peaks in the early morning and then decreases to the minimum in the late afternoon, following the diurnal trend of $\mathrm{NO}_{x}$ (Fig. 2). The daily variations of HONO in Nanjing are like those seen in other urban areas (Villena et al., 2011a; Wang et al., 2013; Michoud et al., 2014; Lee et al., 2016), but differ from observations on the roadside (Rappenglück et al., 2013; Xu et al., 2015). At night, the mixing ratio of HONO increases rapidly in the first few hours and then stabilizes (in spring and summer) or gradually climbs to its peak in the morning rush hour (in winter and autumn). The accumulation during nighttime hours suggests a significant production of $\mathrm{HONO}$ exceeding the dry deposition of HONO. As the sun rises, the HONO sink will be strengthened by the photolysis and vertical mixing processes, resulting in the peak times of the diurnal patterns of HONO concentration varying in different seasons. During the daytime, the rate of HONO abatement is rapid before noon and then becomes progressive until HONO concentration falls to the minimum. Given that the photolytic lifetime of HONO is about 10-20 min at midday (Stutz et al., 2000), the considerable HONO concentration during daytime indicates the existence of strong production of HONO.

From the daily variations of the HONO-to- $\mathrm{NO}_{x}$ ratio, we can further understand the behavior of HONO in the atmosphere. The $\mathrm{HONO} / \mathrm{NO}_{x}$ ratio is regularly enhanced quickly before midnight then reaches a maximum during the latter half of the night. According to Stutz et al. (2002), the highest $\mathrm{HONO} / \mathrm{NO}_{x}$ (or $\mathrm{HONO} / \mathrm{NO}_{2}$ ) is defined by the balance between production and loss of HONO each night; the conditions affecting the highest achievable ratio at nighttime will be discussed in Sect. 3.3. What is interesting here is the peak of the $\mathrm{HONO} / \mathrm{NO}_{x}$ ratio in the midday sun in spring, summer and autumn, and even in winter, the ratio does not decline, but remains stationary before and at noon. If the HONO sources during the daytime are consistent with those at night, the minimum $\mathrm{HONO} / \mathrm{NO}_{x}$ ratio should occur at noon due to the intense photochemical loss of HONO. Therefore, there must be additional sources of HONO during daytime (e.g., Reaction R3). The increase in $\mathrm{HONO} / \mathrm{NO}_{x}$ with 

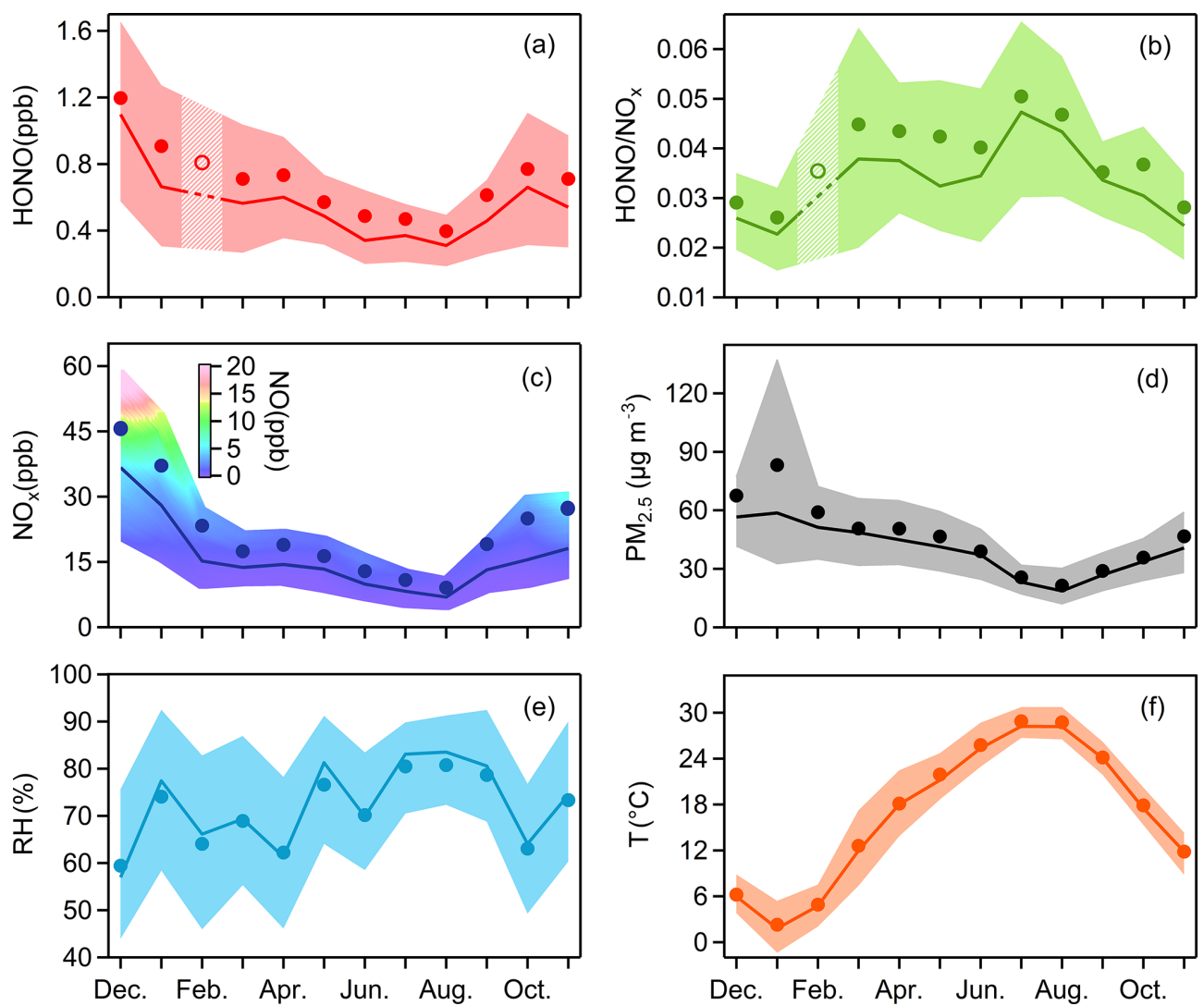

Figure 1. Monthly variations of (a) $\mathrm{HONO}$, (b) $\mathrm{HONO} / \mathrm{NO}_{x}$, (c) $\mathrm{NO}_{x}$, (d) $\mathrm{PM}_{2.5}$, (e) $\mathrm{RH}$ and (f) $T$. The solid bold lines are median values, the markers indicate mean values, and the shaded areas represent percentiles of $75 \%$ and $25 \%$. In (a) and (b), values in February are linearly interpolated based on the data from the months before and after, since there were only a few days when HONO was observed in February. In (c), the shaded area is colored by the 25 th to 75 th percentiles of NO.

solar radiation (e.g., UVB) is found in both diurnal and seasonal variations, indicating that these daytime sources have a relationship with the intensity of solar radiation. We will further discuss the potential daytime sources of HONO in Sect. 3.4.

The elevated mixing ratio of $\mathrm{HONO}$ presents an efficient source of $\mathrm{OH}$ radicals during daytime in Nanjing. We calculate the $\mathrm{OH}$ production rate from $\mathrm{HONO}$, i.e., $P_{\mathrm{OH}}(\mathrm{HONO})$, using Eq. (3). As discussed in Su et al. (2008b) and $\mathrm{Li}$ et al. (2014), HONO produced by the reaction of NO with $\mathrm{OH}$ (Reaction R3) is actually a temporary reservoir of $\mathrm{OH}$ radicals. The photolysis of HONO from this pathway only regenerates $\mathrm{OH}$ radicals and cannot contribute to the concentrations of $\mathrm{OH}$ radicals. So it is inappropriate to estimate the primary $\mathrm{OH}$ production from $\mathrm{HONO}$ based on $\mathrm{P}_{\mathrm{OH}}(\mathrm{HONO})$ derived from Eq. (3). For comparison, the $\mathrm{OH}$ production rate from ozone photolysis, $P_{\mathrm{OH}}\left(\mathrm{O}_{3}\right)$, is derived from Eq. (4). Only part of the $\mathrm{O}\left({ }^{1} \mathrm{D}\right)$ atoms, formed by the photolysis of $\mathrm{O}_{3}$ at wavelengths below $320 \mathrm{~nm}$ (Reaction R7), can produce $\mathrm{OH}$ radicals by reacting with water (Reaction $\mathrm{R} 8$ ) in the atmosphere, so we use the absolute water concentration, which can be derived from relative humidity and tempera- ture, to calculate the branching ratio of $\mathrm{O}\left({ }^{1} \mathrm{D}\right)\left(\phi_{\mathrm{OH}}\right)$ between Reactions (R8) and (R9). The reaction rate of $\mathrm{O}\left({ }^{1} \mathrm{D}\right)$ with $\mathrm{O}_{2}$ is $4.0 \times 10^{-11} \mathrm{~cm}^{3}$ molecules ${ }^{-1} \mathrm{~s}^{-1}$ and the reaction rate of $\mathrm{O}\left({ }^{1} \mathrm{D}\right)$ with $\mathrm{N}_{2}$ is $3.1 \times 10^{-11} \mathrm{~cm}^{3}$ molecules ${ }^{-1} \mathrm{~s}^{-1}$ (Seinfeld and Pandis, 2016). In addition to the two mechanisms mentioned above, there are other pathways to generate primary $\mathrm{OH}$ radicals: the photolysis of aldehydes, mainly $\mathrm{HCHO}$, can form $\mathrm{HO}_{2}$ radicals and then convert to $\mathrm{OH}$ radicals by reacting with $\mathrm{NO}$; the reactions of ozone with alkenes produce OH radicals directly (Finlayson-Pitts and Pitts, 2000; Seinfeld and Pandis, 2016).

$$
\begin{aligned}
& P_{\mathrm{OH}}(\mathrm{HONO})=\mathrm{J}(\mathrm{HONO})[\mathrm{HONO}] \\
& P_{\mathrm{OH}}\left(\mathrm{O}_{3}\right)=2 \mathrm{~J}\left(\mathrm{O}^{1} \mathrm{D}\right)\left[\mathrm{O}_{3}\right] \phi_{\mathrm{OH}} \\
& \phi_{\mathrm{OH}}=k_{8}\left[\mathrm{H}_{2} \mathrm{O}\right] /\left(k_{8}\left[\mathrm{H}_{2} \mathrm{O}\right]+k_{9}[\mathrm{M}]\right) \\
& \mathrm{O}_{3}+h v \rightarrow \mathrm{O}\left({ }^{1} \mathrm{D}\right)+\mathrm{O}_{2}(\lambda<320 \mathrm{~nm}) \\
& \mathrm{O}\left({ }^{1} \mathrm{D}\right)+\mathrm{H}_{2} \mathrm{O} \rightarrow 2 \mathrm{OH} \\
& \mathrm{O}\left({ }^{1} \mathrm{D}\right)+\mathrm{M} \rightarrow \mathrm{O}\left({ }^{3} \mathrm{P}\right)+\mathrm{M}\left(\mathrm{M} \text { is } \mathrm{N}_{2} \text { or } \mathrm{O}_{2}\right)
\end{aligned}
$$

Figure 3 shows that the diurnal peak of $\mathrm{OH}$ production rate from HONO is usually found in the late morning, caused by 
Table 2. Overview of the measured $\mathrm{HONO}$ and $\mathrm{NO}_{x}$ levels in Nanjing and comparison with other urban or suburban sites.

\begin{tabular}{|c|c|c|c|c|c|c|c|c|c|c|c|c|}
\hline Location & Date & \multicolumn{2}{|c|}{ HONO (ppb) } & \multicolumn{2}{|c|}{$\mathrm{NO}_{2}(\mathrm{ppb})$} & \multicolumn{2}{|c|}{$\mathrm{NO}_{x}(\mathrm{ppb})$} & \multicolumn{2}{|c|}{$\mathrm{HONO} / \mathrm{NO}_{2}$} & \multicolumn{2}{|c|}{$\mathrm{HONO} / \mathrm{NO}_{x}$} & Ref \\
\hline Rome (Italy) & May-Jun 2001 & 1.00 & 0.15 & 27.2 & 4.0 & 51.2 & 4.2 & 0.037 & 0.038 & 0.020 & 0.036 & 1 \\
\hline Tokyo (Japan) & Jan-Feb 2004 & 0.80 & 0.05 & 31.8 & 18.2 & 37.4 & 26.3 & 0.025 & 0.003 & 0.021 & 0.002 & 3 \\
\hline Santiago (Chile) & Mar 2005 & 3.00 & 1.50 & 30.0 & 20.0 & 200.0 & 40.0 & 0.100 & 0.075 & 0.015 & 0.038 & 4 \\
\hline Mexico City (Mexico) & Mar 2006 & - & 0.43 & - & 28.4 & - & 44.8 & - & 0.015 & - & 0.010 & 5 \\
\hline \multirow[t]{4}{*}{ Hongkong (China) } & Aug 2011 & 0.66 & 0.70 & 21.8 & 18.1 & 29.3 & 29.3 & 0.031 & 0.042 & 0.025 & 0.028 & \multirow[t]{4}{*}{8} \\
\hline & Nov 2011 & 0.95 & 0.89 & 27.2 & 29.0 & 37.2 & 40.6 & 0.034 & 0.030 & 0.028 & 0.021 & \\
\hline & Feb 2012 & 0.88 & 0.92 & 22.2 & 25.8 & 37.8 & 48.3 & 0.036 & 0.035 & 0.025 & 0.020 & \\
\hline & May 2012 & 0.33 & 0.40 & 14.7 & 15.0 & 19.1 & 21.1 & 0.022 & 0.030 & 0.019 & 0.022 & \\
\hline Beijing (China) & Oct-Nov 2014 & 1.75 & 0.93 & 37.6 & 35.3 & 94.5 & 53.4 & 0.047 & 0.026 & 0.019 & 0.017 & 9 \\
\hline Jinan (China) & Jun-Aug 2016 & 1.20 & 1.01 & 22.5 & 19.0 & 29.1 & 25.8 & 0.106 & 0.079 & 0.060 & 0.049 & 11 \\
\hline \multirow[t]{5}{*}{ Nanjing (China) } & Nov 2017-Nov 2018 & 0.80 & 0.57 & 18.9 & 13.9 & 24.9 & 19.3 & 0.045 & 0.044 & 0.041 & 0.036 & \multirow[t]{5}{*}{ this study } \\
\hline & Dec-Feb (winter) & 1.15 & 0.92 & 28.4 & 23.1 & 45.5 & 37.7 & 0.040 & 0.038 & 0.029 & 0.025 & \\
\hline & Mar-May (spring) & 0.76 & 0.59 & 17.4 & 12.9 & 19.1 & 15.9 & 0.048 & 0.049 & 0.046 & 0.042 & \\
\hline & Jun-Aug (summer) & 0.56 & 0.34 & 12.5 & 7.7 & 13.5 & 9.1 & 0.048 & 0.051 & 0.046 & 0.045 & \\
\hline & Sep-Nov (autumn) & 0.81 & 0.51 & 18.9 & 13.4 & 25.1 & 17.7 & 0.044 & 0.035 & 0.039 & 0.029 & \\
\hline
\end{tabular}

(1) Acker et al. (2006); (2) Yu et al. (2009); (3) Kanaya et al. (2007); (4) Elshorbany et al. (2009); (5) Dusanter et al. (2009); (6) Wong et al. (2011); (7) Bernard et al. (2016); (8) Xu et al. (2015); (9) Tong et al. (2015); (10) Huang et al. (2017); (11) Li et al. (2018).
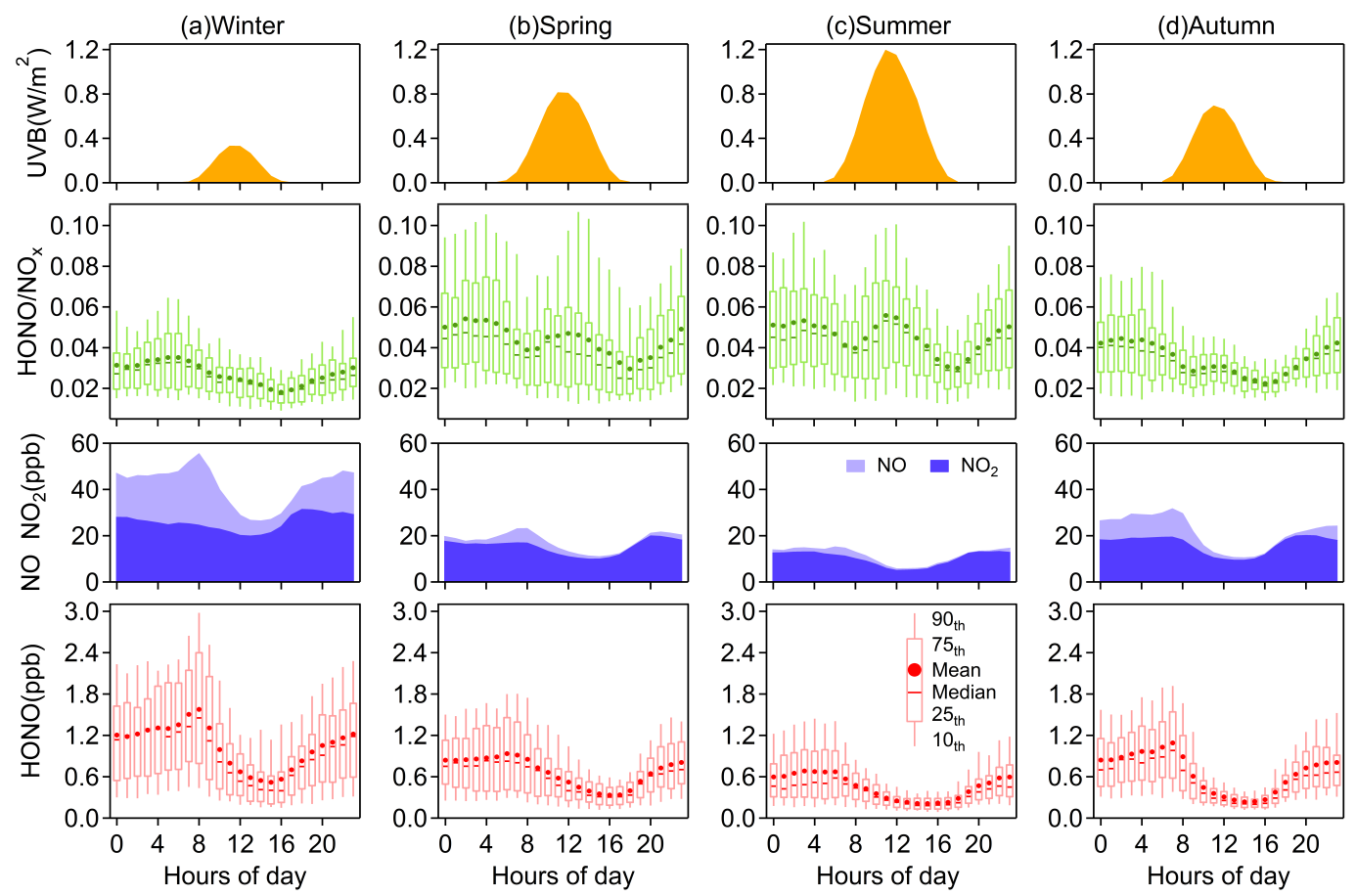

Figure 2. Diurnal variations of $\mathrm{HONO}, \mathrm{NO}, \mathrm{NO}_{2}, \mathrm{HONO} / \mathrm{NO}_{x}$, and $\mathrm{UVB}$ in (a) winter, (b) spring, (c) summer, and (d) autumn. The levels of $\mathrm{NO}, \mathrm{NO}_{2}$ and UVB are displayed as their mean concentrations. 
the combined effects of HONO concentration and its photolysis frequency, and the seasonal peak of $P_{\mathrm{OH}}(\mathrm{HONO})$ occurs in spring for the same reason. $P_{\mathrm{OH}}\left(\mathrm{O}_{3}\right)$, coinciding with the trend of $\mathrm{J}\left(\mathrm{O}^{1} \mathrm{D}\right)$, is highest around noon at a daily timescale and is highest in summer at a seasonal timescale, respectively. Significantly, the photolysis of HONO produces more $\mathrm{OH}$ than that of ozone throughout the daytime in winter, spring, and autumn. In summer, the contribution of HONO to $\mathrm{OH}$ is greater in the early morning, and although the photolysis of ozone contributes more $\mathrm{OH}$ at noon, the role of $\mathrm{HONO}$ is considerable. Overall, the average $P_{\mathrm{OH}}(\mathrm{HONO})$ during 08:00-16:00 LT is $1.16 \mathrm{ppbh}^{-1}$ and the mean value of $P_{\mathrm{OH}}\left(\mathrm{O}_{3}\right)$ is $0.41 \mathrm{ppb} \mathrm{h}^{-1}$. The impressive role of $\mathrm{HONO}$ in the atmospheric oxidizing capacity should benefit photochemical ozone production (Ding et al., 2013; Xu et al., 2017, 2018), new particle formation (Qi et al., 2015) and secondary aerosol formation (Xie et al., 2015; Sun et al., 2018) in Nanjing, western YRD region.

\subsection{Direct emissions of HONO from combustion}

As mentioned above, the good correlation of HONO with $\mathrm{NO}_{x}$ (Fig. 4a) and the similar patterns of HONO and $\mathrm{NO}_{x}$, particularly sharply increasing together in the fresh plumes, in which the $\mathrm{NO} / \mathrm{NO}_{x}$ ratios are usually very high (Fig. S2), indicate the presence of direct combustion emission of HONO, which need to be deducted when analyzing the secondary formation of HONO. The SORPES station is influenced by air masses from both industries and vehicles (Ding et al., 2016), so the traffic emission factor investigated in other experiments cannot be used directly. We derive the emitted $\mathrm{HONO} / \mathrm{NO}_{x}$ ratio according to the method of Xu et al. (2015), and the following criteria are adopted to select fresh plumes: (a) $\left[\mathrm{NO}_{x}\right]>40 \mathrm{ppbv}$; (b) $\mathrm{NO} / \mathrm{NO}_{x}>0.85$; (c) good correlation between HONO and $\mathrm{NO}_{x}(r>0.9)$; (d) short duration of plumes $(<=2 \mathrm{~h})$; and (e) $[\mathrm{UVB}]<=0.01 \mathrm{~W} \mathrm{~m}^{-2}$. Then, the slopes of HONO to $\mathrm{NO}_{x}$ in selected plumes were considered the emission ratios in our study.

Within the 1-year dataset, we select 55 freshly emitted plumes satisfying the criteria above (Table S2), of which 20 air masses were found in the morning and evening rush hours; the derived $\mathrm{HONO} / \mathrm{NO}_{x}$ ratios vary from $0.26 \%$ to $1.91 \%$, with a mean value of $0.79 \% \pm 0.36 \%$. Many factors, such as the amount of excess oxygen, the types of fuel used (gasoline, diesel, coal), whether engines are catalystequipped, and whether engines are well-maintained, could result in variances in these ratios. Additionally, the rapid heterogeneous reduction of $\mathrm{NO}_{2}$ on synchronously emitted $\mathrm{BC}$ can also raise the value of $\mathrm{HONO} / \mathrm{NO}_{x}$ (Xu et al., 2015). For our study, an average emission factor of $0.79 \%$ is deployed to evaluate the emission contribution of HONO (Eq. 5), which is abbreviated as $\mathrm{HONO}_{\mathrm{emis}}$.

$\mathrm{HONO}_{\mathrm{emis}}=\mathrm{NO}_{x} \times 0.0079$
$\mathrm{HONO}_{\text {corr }}=\mathrm{HONO}-\mathrm{HONO}_{\mathrm{emis}}$

Combustion emissions contribute an average of $23 \%$ of total measured HONO concentrations at night (Fig. 4b), with a maximum $\mathrm{HONO}_{\mathrm{emis}} / \mathrm{HONO}$ value of $32 \%$ in winter and a minimum $\mathrm{HONO}_{\mathrm{emis}} / \mathrm{HONO}$ value of $18 \%$ in summer. We then get the corrected observed HONO $\left(\mathrm{HONO}_{\text {corr }}\right)$ by Eq. (6) for further analysis. The slope of the fitted line for HONO and $\mathrm{NO}_{x}$ is $1.62 \%$, higher than the emission ratio of $0.79 \%$ (Fig. $4 \mathrm{a}$ ), and almost $80 \%$ of HONO is from $\mathrm{HONO}_{\text {corr }}$ that is not affected by emissions (Fig. 4b). These imply significant secondary formation of HONO in the atmosphere.

\subsection{Heterogeneous conversion of $\mathrm{NO}_{2}$ to $\mathrm{HONO}$ at nighttime}

\subsubsection{The $\mathrm{NO}_{2}$-to-HONO conversion rate $\left(C_{\mathrm{HONO}}\right)$}

In addition to emissions, heterogeneous reactions of $\mathrm{NO}_{2}$ on surfaces (Reactions R4 and R5) are believed to be the major formation pathways of nocturnal $\mathrm{HONO}$. Thus, the $\mathrm{NO}_{2}$-toHONO conversion rate is calculated from Eq. (5) (Alicke et al., 2002; Alicke, 2003; Wentzell et al., 2010), where $\mathrm{NO}_{2}$ is adopted to scale $\mathrm{HONO}$ to reduce the dilution influence according to $\mathrm{Su}$ et al. (2008a). Similarly to $\mathrm{HONO} / \mathrm{NO}_{x}$ (Fig. 2), the nighttime $\mathrm{HONO}_{\text {corr }} / \mathrm{NO}_{2}$ ratio rises from the lowest value and then reaches a quasi-stable state, meaning that $C_{\mathrm{HONO}}$ can actually be used to assess how quickly $\mathrm{HONO}_{\text {corr }} / \mathrm{NO}_{2}$ can increase to its equilibrium.

$C_{\mathrm{HONO}}=\frac{\frac{\left[\mathrm{HONO}_{\text {corr }}\right]_{\left(t_{2}\right)}}{\left[\mathrm{NO}_{2}\right]_{\left(t_{2}\right)}}-\frac{\left[\mathrm{HONO}_{\text {corr }}\right]_{\left(t_{1}\right)}}{\left[\mathrm{NO}_{2}\right]_{\left(t_{1}\right)}}}{t_{2}-t_{1}}$

Following the method of Xu et al. (2015) and Li et al. (2018), 137 cases in which $\mathrm{HONO}_{\text {corr }} / \mathrm{NO}_{2}$ increased almost linearly from 18:00 to 24:00 each night are selected, and the slope fitted by the least linear regression for $\mathrm{HONO}_{\text {corr }} / \mathrm{NO}_{2}$ against time is just the conversion frequency of $\mathrm{NO}_{2}$ to $\mathrm{HONO}$. The derived $C_{\text {HONO }}$ varies from $0.0043 \pm 0.0017 \mathrm{~h}^{-1}$ in winter to $0.0066 \pm 0.0040 \mathrm{~h}^{-1}$ in summer, with an average value of $0.0055 \pm 0.0032 \mathrm{~h}^{-1}$, which is in the range $\left(0.004-0.014 \mathrm{~h}^{-1}\right)$ shown by other studies in urban and suburban sites (Fig. 5). Note that $C_{\mathrm{HONO}}$ assumes all the increase in $\mathrm{HONO}_{\text {corr }} / \mathrm{NO}_{2}$ is caused by the conversion of $\mathrm{NO}_{2}$, excluding other possible sources of $\mathrm{HONO}$ (e.g., soil nitrite); and the computed $C_{\mathrm{HONO}}$ is the net $\mathrm{NO}_{2}$-to-HONO conversion rate since the measured $\mathrm{HONO}_{\text {corr }}$ has already taken the sinks of HONO (mainly deposition) into account. Considering the uncertainties of $C_{\mathrm{HONO}}$, utilizing $C_{\mathrm{HONO}}$ directly to analyze the mechanism of HONO formation thoroughly may not be appropriate, but it could be attemptable to facilitate the parameterizations for HONO production in air quality models by $C_{\mathrm{HONO}}$ when the chemical mechanisms are not clear yet. 

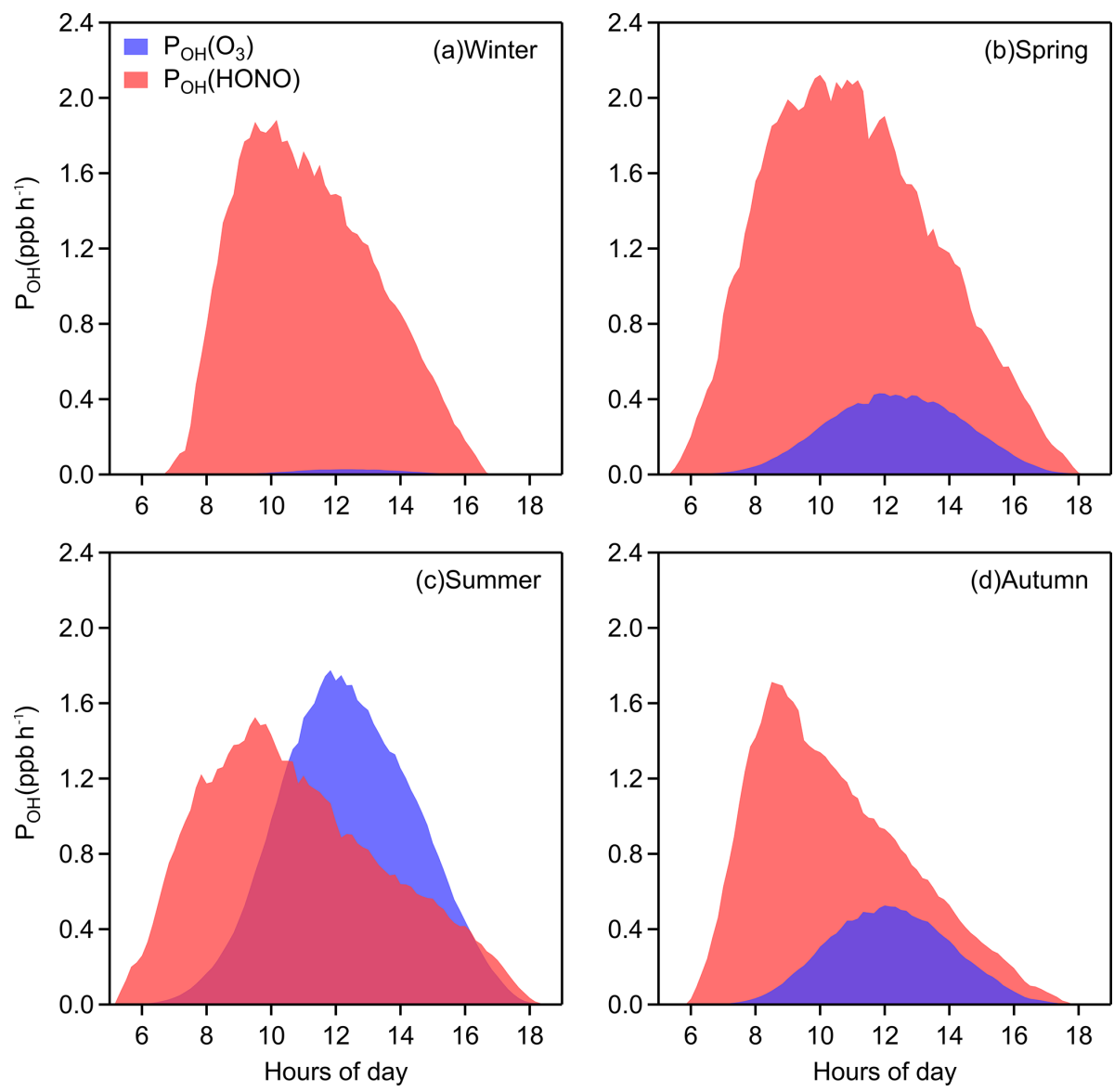

Figure 3. Averaged $\mathrm{OH}$ production rates from photolysis of HONO and ozone in (a) winter, (b) spring, (c) summer, and (d) autumn.

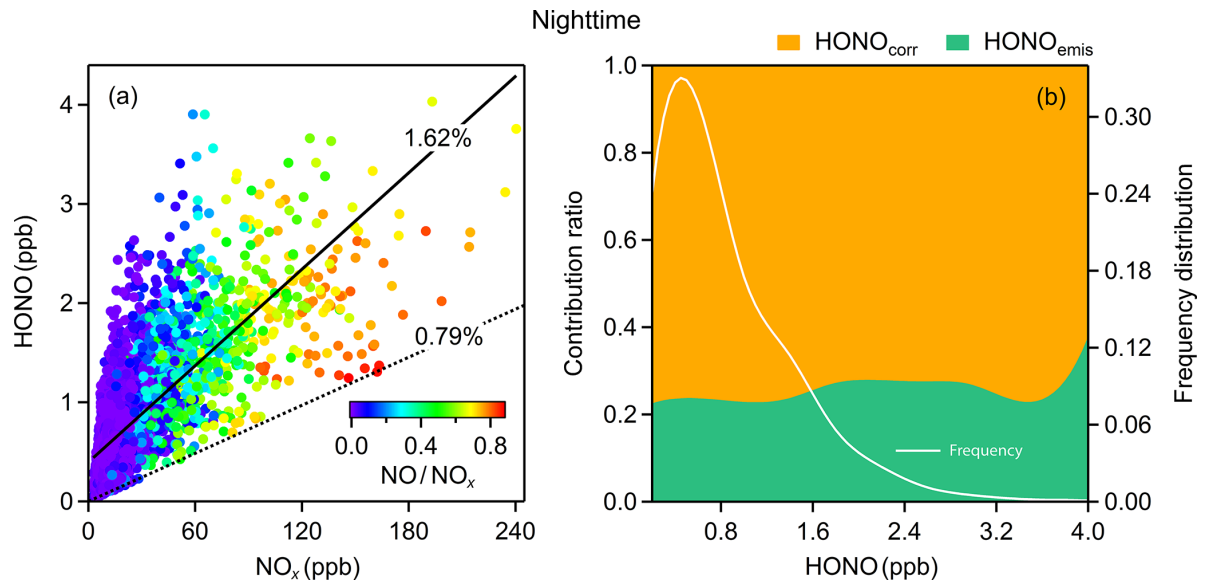

Figure 4. (a) The relationship between $\mathrm{HONO}$ and $\mathrm{NO}_{x}$ colored by the $\mathrm{NO} / \mathrm{NO}_{x}$ ratio. The dotted line is the emission ratio derived in this study and the solid line is obtained from simple linear fitting; (b) average emission contribution ratios for different concentrations of HONO and the frequency distribution of HONO concentrations. Both (a) and (b) are nighttime values. 


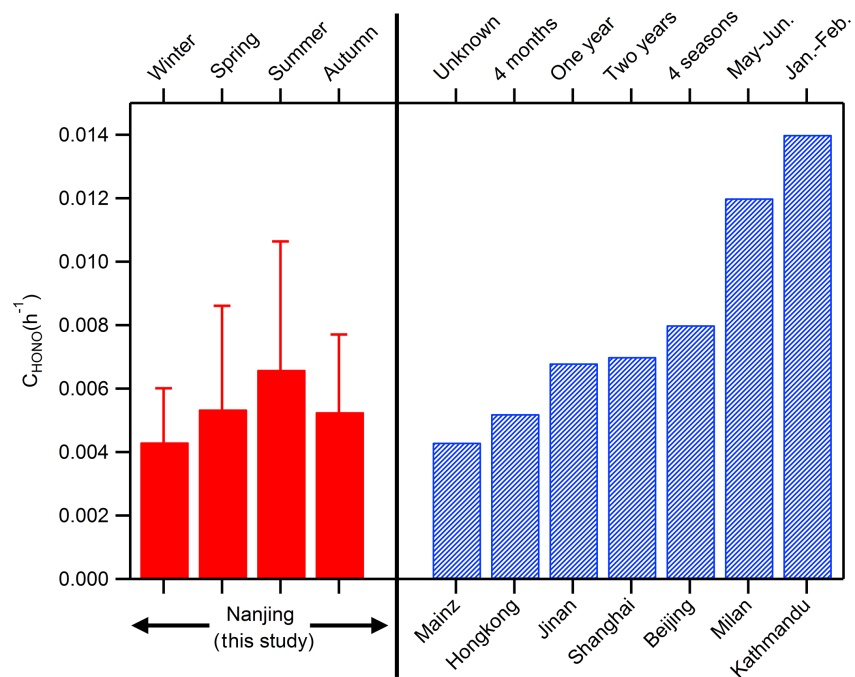

Figure 5. Comparison of observed $\mathrm{NO}_{2}$-to-HONO conversion rates in cities: Nanjing (this study); Mainz (Lammel, 1999); Hongkong (Xu et al., 2015); Jinan (Li et al., 2018); Shanghai (Wang et al., 2013); Beijing (Wang et al., 2017); Milan (Alicke et al., 2002); and Kathmandu (Yu et al., 2009).

\subsubsection{RH dependence of HONO chemistry}

It appears that $\mathrm{NO}_{2}$ hydrolysis on humid surfaces (Reaction R4), having a first-order dependence on $\mathrm{NO}_{2}$ (Jenkin et al., 1988; Ackermann, 2000; Finlayson-Pitts et al., 2003), is influenced by the surface-absorbed water (Kleffmann et al., 1998; Finlayson-Pitts et al., 2003), although the exact mechanisms are still unknown. In the studies of Stutz et al. (2002) and Stutz et al. (2004), the pseudo steady state of $\mathrm{HONO} / \mathrm{NO}_{2}$, where this ratio is at a maximum at nighttime, is presumed to be a balance between the production of $\mathrm{HONO}$ from $\mathrm{NO}_{2}$ and the loss of HONO on surfaces, and the highest $\mathrm{HONO} / \mathrm{NO}_{2}$ value is determined by the ratio of the reactive uptake coefficients for each process. Scatter plots of $\mathrm{HONO}_{\text {corr }} / \mathrm{NO}_{2}$ against relative humidity in our study are illustrated in Fig. 6. To eliminate as much influence of other factors as possible, the average of the six highest $\mathrm{HONO}_{\text {corr }} / \mathrm{NO}_{2}$ values in each $5 \% \mathrm{RH}$ interval is calculated according to Stutz et al. (2004). The phenomenon that $\mathrm{HONO}$ corr $/ \mathrm{NO}_{2}$ first increases and then decreases with an increasing RH in Fig. 6a was also observed by other studies (Hao et al., 2006; Yu et al., 2009; Li et al., 2012; Wang et al., 2013). The dependencies of $\mathrm{HONO}_{\text {corr }} / \mathrm{NO}_{2}$ on RH and the possible reasons or mechanisms are discussed as follows. Even at the lowest measured $\mathrm{RH}$ of $18 \%$, the absolute moisture content in the atmosphere is still greater than $10^{3} \mathrm{ppm}$ in our study, which is quite abundant for reacting with $\mathrm{NO}_{2}$, but the $\mathrm{HONO}_{\text {corr }} / \mathrm{NO}_{2}$ ratio is quite small and remains unchanged when $\mathrm{RH}$ is below $45 \%$, indicating that the $\mathrm{NO}_{2}$ to HONO conversion efficiency should be determined by water

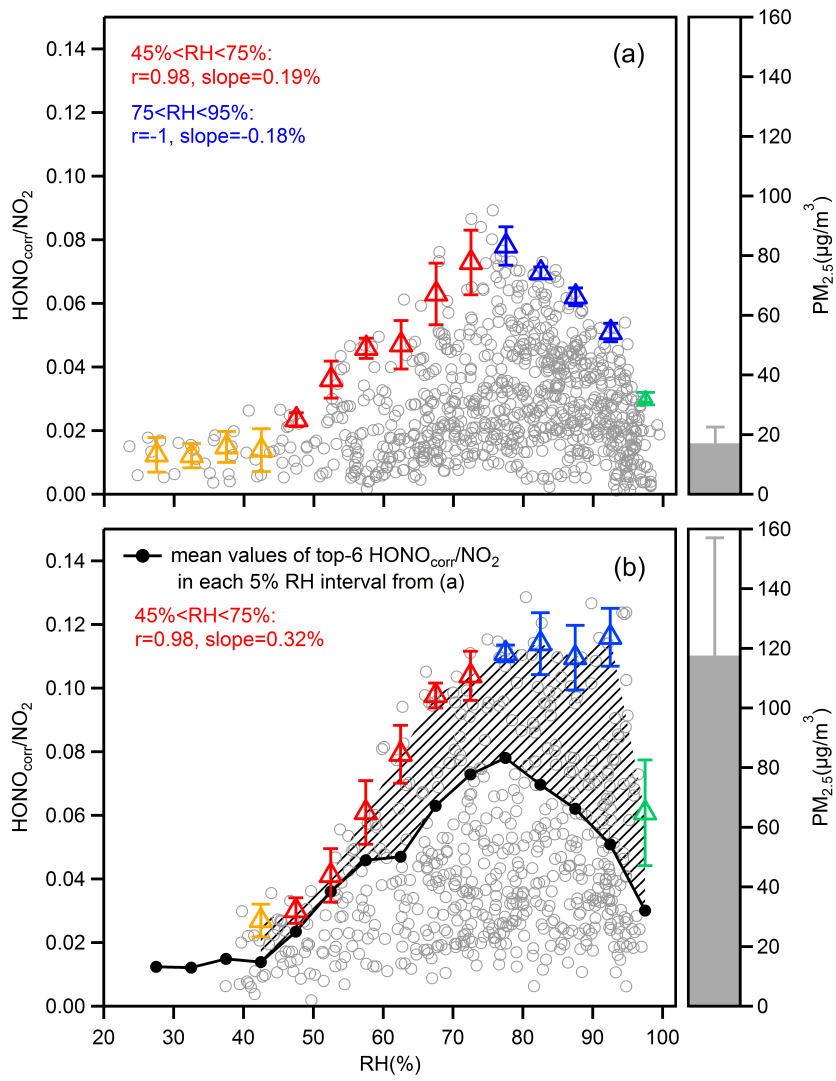

Figure 6. Scatter plots of the $\mathrm{HONO}$ corr $/ \mathrm{NO}_{2}$ ratio and $\mathrm{RH}$ during nighttime, separating the data into (a) clean hours (hourly mean $\mathrm{PM}_{2.5}<25 \mu \mathrm{g} \mathrm{m}^{-3}$ ) and (b) polluted hours (hourly mean $\mathrm{PM}_{2.5}>75 \mu \mathrm{g} \mathrm{m}^{-3}$ ). Triangles are the averaged top-six $\mathrm{HONO}_{\text {corr }} / \mathrm{NO}_{2}$ in each $5 \% \mathrm{RH}$ interval, and the error bars are the standard deviations. The overall average concentrations of $\mathrm{PM}_{2.5}$ in (a) and (b) are shown to the right of the figures.

covering the surfaces rather than by the amount of water in the air.

It has been reported that surfaced absorbed water depends on RH values, and the dependences vary for different material surfaces of the ground, but generally follow the shape of a BET isotherm (Lammel, 1999; Saliba et al., 2001; Sumner et al., 2004). The number of mono-layers of water increases slowly from zero to $2-4$, accompanied by $\mathrm{RH}$ from zero to a turning point, and the water coverage grows dramatically (up to 10-100 mono-layers) once RH exceeds the turning point (Finlayson-Pitts et al., 2003). Figure 6a shows the case where the surface for $\mathrm{NO}_{2}$ converting to $\mathrm{HONO}$ is dominated by the ground and the $\mathrm{HONO}_{\text {corr }} / \mathrm{NO}_{2}$ increases along with $\mathrm{RH}$ when RH is less than $75 \%$, which can be explained by the reaction of $\mathrm{NO}_{2}$ to generate $\mathrm{HONO}$ on wet surfaces. However, a negative correlation between $\mathrm{HONO}_{\text {corr }} / \mathrm{NO}_{2}$ and $\mathrm{RH}$ is found when $\mathrm{RH}$ is over $75 \%$, presumably because the rapidly growing aqueous layers of the ground surface lead to efficient uptake of HONO and make the surface less accessible or less 
reactive to $\mathrm{NO}_{2}$. Hence, the $\mathrm{RH}$ turning point for absorbed water on ground surfaces is perhaps around $75 \%$ for our observation, within the range of results from experiments on various surfaces (RH: 70\%-80\%) (Lammel, 1999; Saliba et al., 2001; Sumner et al., 2004). Once RH exceeds $95 \%$, the reaction surface asymptotically approaches the state of a water droplet, where the quite limited formation of HONO and the extremely impactful loss of HONO will result in a dramatic decline of the $\mathrm{HONO}_{\text {corr }} / \mathrm{NO}_{2}$ ratio (Fig. 6a and b).

Notably, the constant $\mathrm{HONO}$ corr $/ \mathrm{NO}_{2}$ value at $\mathrm{RH}$ between $75 \%$ and $95 \%$ under the condition of high $\mathrm{PM}_{2.5}$ mass loading (Fig. 6b), compared to the downward trend of $\mathrm{HONO}_{\text {corr }} / \mathrm{NO}_{2}$ within the same humidity range in low $\mathrm{PM}_{2.5}$ mass concentration (Fig. 6a), implies a contribution of aerosol surfaces to the $\mathrm{NO}_{2}-\mathrm{HONO}$ conversion. Since both $\mathrm{HONO}_{\text {corr }} / \mathrm{NO}_{2}$ in Fig. $6 \mathrm{a}$ and $\mathrm{b}$ are affected by the ground surfaces, we can use the difference of $\mathrm{HONO}_{\text {corr }} / \mathrm{NO}_{2}$ between the two figures to represent the influence of aerosol. As the area of shadow showed in Fig. 6b, the aerosolaffected $\mathrm{HONO}_{\text {corr }} / \mathrm{NO}_{2}$ is positively related to $\mathrm{RH}$ before $\mathrm{RH}$ reaches $95 \%$. With the increase in $\mathrm{RH}$, the hygroscopic growth of aerosol particles should provide a larger surface area. When RH is higher than $75 \%$, which has exceeded the mutual deliquescence relative humidity of inorganic salts (Fountoukis and Nenes, 2007), aerosols will transfer to aqueous phase gradually and then promote multiphase or heterogeneous chemistry processes (Herrmann et al., 2015). For example, the oxidation of $\mathrm{SO}_{2}$ by $\mathrm{NO}_{2}$ on an aqueous aerosol surface may produce $\mathrm{NO}_{2}^{-} / \mathrm{HONO}$ efficiently under polluted conditions (Xie et al., 2015; Wang et al., 2016). In addition, the enhancement $\mathrm{NO}_{2}$ uptake on micro-droplets by anions has been reported in experiments (Yabushita et al., 2009).

\subsubsection{Impact of aerosols on HONO formation}

To further understand the heterogeneous formation of $\mathrm{HONO}$ on aerosol, we carry out a correlation analysis when $\mathrm{HONO}_{\text {corr }} / \mathrm{NO}_{2}$ reaches the pseudo steady state at each night (03:00-06:00 LT). The convergence or diffusion processes of gases and particles can also lead to a consistent trend of $\mathrm{HONO}_{\text {corr }}$ and $\mathrm{PM}_{2.5}$ (Fig. 7a), while the ratio of $\mathrm{HONO}_{\text {corr }}$ and $\mathrm{NO}_{2}$ can not only reduce this physical effect, but can also represent the conversion degree of $\mathrm{NO}_{2}$ to $\mathrm{HONO}$, so a moderate positive correlation between $\mathrm{HONO}_{\text {corr }} / \mathrm{NO}_{2}$ and $\mathrm{PM}_{2.5}(r=0.35, p=0.01)$ throughout the observation period could be more believable (Fig. 7b). As shown by larger triangles with gray borders in Fig. $7 \mathrm{~b}, \mathrm{HONO}_{\text {corr }} / \mathrm{NO}_{2}$ is better correlated with $\mathrm{PM}_{2.5}$ in the months when the mass concentrations of $\mathrm{PM}_{2.5}$ are higher during this 1-year measurement, generally occurring from November to May (Fig. 1d). This finding can be explained with a law that greater contributions of $\mathrm{NO}_{2}$ heterogeneously reacting on aerosol surface to $\mathrm{HONO}$ cause better correlations between $\mathrm{HONO}$ corr $/ \mathrm{NO}_{2}$ and $\mathrm{PM}_{2.5}$. Interestingly, this relationship can also be divided approximately into two groups by $\mathrm{NH}_{3} / \mathrm{CO}$; the correlation is good when the value of $\mathrm{NH}_{3} / \mathrm{CO}$ is lower than $2 \%$, but when $\mathrm{NH}_{3} / \mathrm{CO}$ is higher than $2 \%$, a poor correlation is found. We will discuss this phenomenon further in Sect. 4. The evidence of HONO formation on aerosol was also found in other observations (Reisinger, 2000; Wang, 2003; Li et al., 2012; Nie et al., 2015; Hou et al., 2016; Cui et al., 2018).

As is known, producing HONO is not the dominant sink of $\mathrm{NO}_{2}$ at night, but it seems that more $\mathrm{NO}_{2}$ can be converted to HONO under conditions of heavy pollution (Fig. 7b). We discuss whether heterogeneous reactions of $\mathrm{NO}_{2}$ on aerosols are able to provide comparable HONO with our measurement by Eq. (8), only considering HONO formation on particle surfaces and assuming that HONO principally settles on the ground surface, neglecting $\mathrm{HONO}$ loss on aerosol. $c_{\mathrm{NO}_{2}}$ is the mean molecular velocity of $\mathrm{NO}_{2}\left(370 \mathrm{~m} \mathrm{~s}^{-1}\right) ;\left[\frac{S}{V}\right]_{\mathrm{aer}}$ is the surface area to volume ratio $\left(\mathrm{m}^{-1}\right)$ of aerosol; $\nu_{\mathrm{HONO}}$ is the deposition velocity of $\mathrm{HONO}$, which is considered to be close to the deposition velocity of $\mathrm{NO}_{2}$ at night (Stutz et al., 2002; Su et al., 2008a); and an approximate value of $0.1 \mathrm{~cm} \mathrm{~s}^{-1}$ is used based on the measurements from Coe and Gallagher (1992) and Stutz et al. (2002); $H$ is the boundary layer mixing depth, and a value of $100 \mathrm{~m}$ is assumed for nighttime (Su et al., 2008a).

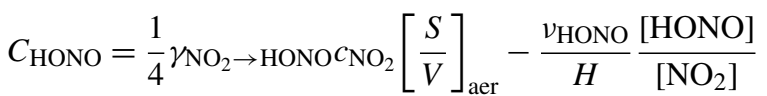

Considering the nighttime period with severe haze, the aerosol surface density calculated from the particle number size distributions between 6 and $800 \mathrm{~nm}$ is about $1.2 \times$ $10^{-3} \mathrm{~m}^{-1}$, matched by $200 \mu \mathrm{g} \mathrm{m}^{-3}$ of $\mathrm{PM}_{2.5}$ from our observations, and the averaged mixing ratios of HONO and $\mathrm{NO}_{2}$ are 1.15 and $28.4 \mathrm{ppb}$, respectively (Table 2). For $30 \%-$ $100 \%$ of the measured mean $C_{\mathrm{HONO}}\left(0.0043 \mathrm{~h}^{-1}\right)$ in winter, the uptake coefficient of $\mathrm{NO}_{2}$ to $\mathrm{HONO}\left(\gamma_{\left.\mathrm{NO}_{2} \rightarrow \mathrm{HONO}\right)}\right)$ calculated from Eq. (8) is in the range of $6.9 \times 10^{-6}$ to $1.44 \times 10^{-5}$, consistent with the results from many laboratory studies which demonstrate that the uptake coefficients of $\mathrm{NO}_{2}\left(\gamma_{\mathrm{NO}_{2}}\right)$ on multiple aerosol surfaces or wet surfaces are mainly distributed around $10^{-5}$, with the HONO yield varying from 0.1 to 0.9 (Grassian, 2002; Aubin and Abbatt, 2007; Khalizov et al., 2010; Han et al., 2017). It is necessary to elaborate that (1) the ambient particles were dried with silica gel before measuring their number size distributions, and the mass concentrations of $\mathrm{PM}_{2.5}$ were also measured under a system where the temperature was maintained at $30^{\circ}$, usually above ambient temperature; (2) the aerosol surface was calculated by assuming that all particles are spherically shaped, but the particles could in fact have irregular bodies and a porous structure; (3) the particle size of both $\mathrm{PM}_{2.5}$ and derived $\left[\frac{S}{V}\right]_{\text {aer }}$ is just a part of the total suspended particulate matter. As described, the aerosol surface in the atmosphere is actually underestimated in our study, and thus the $\gamma \mathrm{NO}_{2} \rightarrow \mathrm{HONO}$ we derived could be the upper limit of the uptake coefficient for $\mathrm{NO}_{2}$ conversion to HONO on aerosol. In addition to particle surfaces, other aerosol parameters such as 

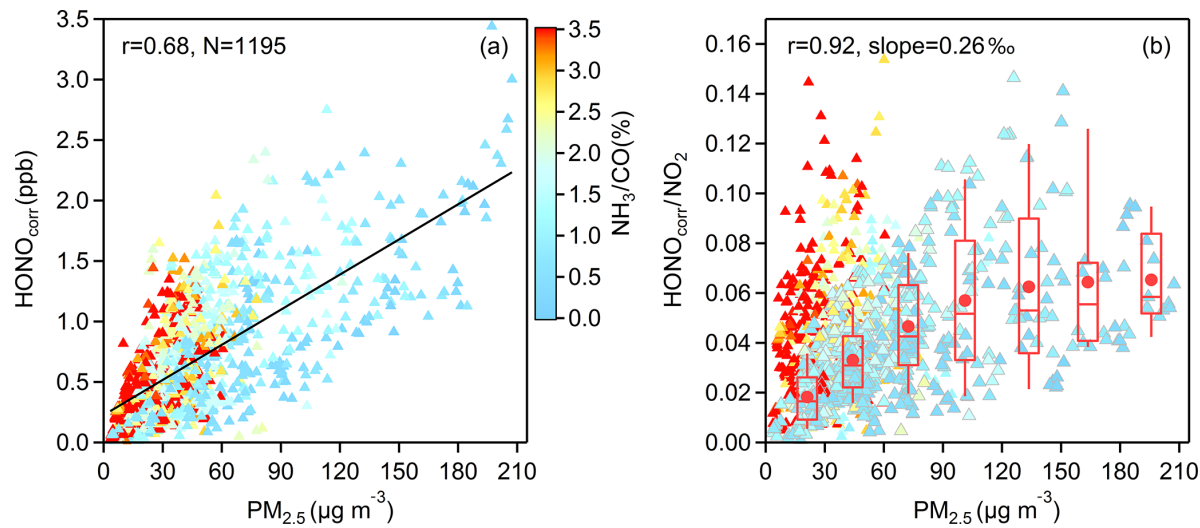

Figure 7. (a) The correlation between $\mathrm{HONO}_{\text {corr }}$ and $\mathrm{PM}_{2.5}$ and (b) the correlation between $\mathrm{HONO}_{\text {corr }} / \mathrm{NO}_{2}$ and $\mathrm{PM}_{2.5}$; all scatters come from the time (03:00-06:00 LT) when the $\mathrm{HONO}_{\text {corr }} / \mathrm{NO}_{2}$ ratio reaches the pseudo steady state each night and are colored by $\mathrm{NH}_{3} / \mathrm{CO}$. In (b), the larger triangles with gray borders depict the measured data from November to May, and the boxplot in each $30 \mu \mathrm{g} \mathrm{m}{ }^{-3}$ interval of $\mathrm{PM}_{2.5}$ is illustrated according to the same data, the red box boundaries represent interquartile range, the whiskers represent the $10 \%-90 \%$ percentile range, the horizontal red lines represent median values, and the red markers represent mean values. The correlation coefficient and the slope of the linearly fitted line in (b) are derived from the averaged $\mathrm{HONO}_{\text {corr }} / \mathrm{NO}_{2}$ and averaged $\mathrm{PM}_{2.5}$ in each box.

surface water content, chemical composition, $\mathrm{pH}$ value, and phase state of surfaces may also influence the heterogeneous formation of HONO.

\subsection{Missing daytime HONO source}

After discussing the nocturnal formation mechanism of $\mathrm{HONO}$, we now focus on the chemistry of daytime HONO whose concentrations are still about $0.25-0.6 \mathrm{ppb}$ at noon with a lifetime of only 10-20 min (Fig. 2). We are not certain whether the observed HONO can be provided by known mechanisms (gas-phase Reaction R4 and emissions) to date, so a budget equation of daytime HONO (Eq. 9) is utilized to analyze its sources and sinks (Su et al., 2008b; Sörgel et al., 2011). Here, $d H O N O / d t$ is the change rate of the observed HONO. The source rates of HONO contain the homogeneous formation rate $\left(P_{\mathrm{NO}+\mathrm{OH}}\right.$, Reaction R3); the combustion emission rate $\left(P_{\mathrm{emis}}\right)$; and the unknown HONO daytime source $\left(P_{\text {unknown }}\right)$. The sink rates of HONO consist of the photolysis rate $\left(L_{\mathrm{phot}}\right.$, Reaction R1); the reaction rate of $\mathrm{HONO}$ with $\mathrm{OH}\left(L_{\mathrm{HONO}+\mathrm{OH}}\right.$, Reaction R2); and the dry deposition rate $\left(L_{\mathrm{dep}}\right) . T_{\mathrm{v}}$ and $T_{\mathrm{h}}$ represent the vertical $\left(T_{\mathrm{V}}\right)$ and horizontal $\left(T_{\mathrm{h}}\right)$ transport processes of HONO, which are thought to be negligible for intense radiation and relatively homogeneous atmospheres with generally calm winds (Dillon et al., 2002; Su et al., 2008b; Sörgel et al., 2011).

$$
\begin{aligned}
\frac{\mathrm{dHONO}}{\mathrm{d} t} & =\left(P_{\mathrm{NO}+\mathrm{OH}}+P_{\mathrm{emis}}+P_{\text {unknown }}\right) \\
& -\left(L_{\mathrm{phot}}+L_{\mathrm{HONO}+\mathrm{OH}}+L_{\mathrm{dep}}\right)+T_{\mathrm{v}}+T_{\mathrm{h}}
\end{aligned}
$$

Therefore, the undiscovered daytime source of HONO ( $\left.P_{\text {unknown }}\right)$ can be derived by Eq. (10), which is a deformation of Eq. (9) without minor terms $\left(T_{\mathrm{V}}\right.$ and $\left.T_{\mathrm{h}}\right)$ and where $\mathrm{dHONO} / \mathrm{d} t$ is substituted by $\Delta \mathrm{HONO} / \Delta t$ that is counted as the difference between observed HONO at two time points. The reaction rate constants of Reaction (R2) $\left(k_{\mathrm{HONO}+\mathrm{OH}}\right)$ and Reaction (R3) $\left(k_{\mathrm{NO}+\mathrm{OH}}\right)$ are $6.0 \times 10^{-12} \mathrm{~cm}^{3}$ molecules ${ }^{-1} \mathrm{~s}^{-1}$ and $9.8 \times$ $10^{-12} \mathrm{~cm}^{3}$ molecules ${ }^{-1} \mathrm{~s}^{-1}$, respectively (Atkinson et al., 2004). The emission ratio of $\mathrm{HONO}$ to $\mathrm{NO}_{x}\left(\mathrm{HONO} / \mathrm{NO}_{x}=\right.$ $0.79 \%$ ) obtained in Sect. 3.2 is used to estimate $P_{\text {emis }}$. For $L_{\mathrm{dep}}$, the dry deposition velocity of diurnal HONO $\left(v_{\mathrm{HONO}}\right)$ is measured as $2 \mathrm{~cm} \mathrm{~s}^{-1}$ in the work of Harrison et al. (1996), and a practical mixing height of $200 \mathrm{~m}$ is adopted, considering that most of the HONO cannot rise above this altitude due to rapid photolysis (Alicke et al., 2002). Although we did not observe $\mathrm{OH}$ radicals directly, the uncertainty of $P_{\text {unknown }}$ caused by the calculated $\mathrm{OH}$ radicals from Eq. (2) can be reduced substantially in the case of a low concentration of $\mathrm{NO}$ and a high value of $\mathrm{J}\left(\mathrm{O}^{1} \mathrm{D}\right)$ (Fig. S1d).

$$
\begin{aligned}
P_{\text {unknown }} & =\mathrm{J}(\mathrm{HONO})[\mathrm{HONO}] \\
& +k_{\mathrm{HONO}+\mathrm{OH}}[\mathrm{HONO}][\mathrm{OH}] \\
& +\frac{v_{\mathrm{HONO}}}{H}[\mathrm{HONO}]+\frac{\Delta \mathrm{HONO}}{\Delta t} \\
& -k_{\mathrm{NO}+\mathrm{OH}}[\mathrm{NO}][\mathrm{OH}]-\frac{0.79 \% \times \Delta \mathrm{NO}_{x}}{\Delta t}
\end{aligned}
$$

Figure 8 shows the average daytime HONO budgets from 08:00 to 16:00 LT during different seasons. The major loss route of HONO is photodecomposition ( $L_{\text {phot }}$ ) with an average value of $1.50 \mathrm{ppbh}^{-1}$ around noontime (10:0014:00 LT); the next is dry deposition $\left(L_{\mathrm{dep}}\right)$, whose mean value at the same time is $0.21 \mathrm{ppbh}^{-1}$, and by $L_{\mathrm{HONO}+\mathrm{OH}}$, which is less than $5 \%$ of that of $L_{\text {phot }}$. For the sources of $\mathrm{HONO}$ around noon, the average homogeneous reaction rate between $\mathrm{NO}$ and $\mathrm{OH}\left(P_{\mathrm{NO}+\mathrm{OH}}\right)$ is $0.63 \mathrm{ppb} \mathrm{h}^{-1}$, and $P_{\text {emis }}$ just gives a tiny part of $\mathrm{HONO}$ at a rate of $0.02 \mathrm{ppbh}^{-1}$, 
meaning that most HONO comes from an unknown source whose average rate $\left(P_{\text {unknown }}\right)$ is $1.04 \mathrm{ppbh}^{-1}$, contributing about $61 \%$ of the production of HONO. Comparing summer data, the mean unknown daytime source strength of HONO in Nanjing is almost at the upper-middle level of those reported in the existing literature: $0.22 \mathrm{ppbh}^{-1}$ at a rural site of New York State, USA (Zhou et al., 2002); $0.5 \mathrm{ppb} \mathrm{h}^{-1}$ in a forest near Jülich, Germany (Kleffmann, 2005); $0.77 \mathrm{ppb} \mathrm{h}^{-1}$ in a polluted rural area of the Pearl River delta, China ( $\mathrm{Li}$ et al., 2012); $0.98 \mathrm{ppb} \mathrm{h}^{-1}$ at an urban site in Xi'an, China (Huang et al., 2017); $1.7 \mathrm{ppb} \mathrm{h}^{-1}$ in an urban area of Santiago, Chile (Elshorbany et al., 2009); and $2.95 \mathrm{ppbh}^{-1}$ in the urban atmosphere of Jinan, China (Li et al., 2018). In our study, the $\mathrm{OH}$ production rate from the missing $\mathrm{HONO}$ accounts for about $53 \%$ of total $P_{\mathrm{OH}}(\mathrm{HONO}$ ) (Fig. S2), suggesting that the unconventional source of HONO is of significance to atmospheric oxidation.

Hence, we perform a correlation analysis to explore the potential unknown daytime mechanisms of HONO (Table 3). $P_{\text {unknown }}$ is better correlated with $\mathrm{NO}_{2} \times \mathrm{UVB}$ than with $\mathrm{NO}_{2}$ or UVB alone in winter, spring and autumn $(p=0.05)$, perhaps associated with the photo-enhanced conversion from $\mathrm{NO}_{2}$ to HONO (George et al., 2005; Stemmler et al., 2006, 2007). The average value of $P_{\text {unknown }}$ normalized by $\mathrm{NO}_{2}$ is $0.1 \mathrm{~h}^{-1}$, over 18 times greater than the nighttime conversion rate $\left(0.0055 \mathrm{~h}^{-1}\right)$, also implying that $P_{\text {unknown }}$ cannot be explained by the nocturnal mechanism of $\mathrm{NO}_{2}$ to HONO. Assuming that the height of a well-mixed boundary layer around noon remains constant for each day, $\mathrm{UVB} \times \mathrm{NO}_{2}$ and $\mathrm{UVB} \times \mathrm{NO}_{2} \times \mathrm{PM}_{2.5}$ could be proxies for photo-induced heterogeneous reactions of $\mathrm{NO}_{2}$ on ground and aerosol surfaces, respectively. We do not have any solid evidence to identify which surfaces (ground or aerosol) are more important to the photo-heterogeneous reaction of $\mathrm{NO}_{2}$ based on the present analysis. For the same reason, the photolysis of particulate nitrates $\left(\mathrm{NO}_{3}^{-}\right)$as a source of $\mathrm{HONO}$ (Ye et al., 2016, 2017) cannot be determined as momentous in our study. The comparisons of correlation coefficients shown above follow the method provided by Meng et al. (1992).

Our study suggests that the missing source of HONO should be considered in the air quality forecasting or regional models to characterize atmospheric oxidizing capacity better, especially in warm seasons (spring and summer). Based on the measurement (Fig. S3), the light-induced heterogeneous conversion of $\mathrm{NO}_{2}$ to $\mathrm{HONO}$ on aerosol surfaces and ground surfaces can probably be included in simulation works, as was done in Lee et al. (2016).

\section{Semi-quantitative estimation of the contribution from different sources}

From this and previous studies, we can conclude that not only the concentration but also the sources of HONO have temporal and spatial patterns, which is supposed to be considered in model studies. Nocturnal HONO is selected to discuss the monthly variations of HONO sources in detail without the uncertainties of daytime HONO formation, the influences of HONO photolysis, and the mixing effect of the boundary layer. The heterogeneous reaction of $\mathrm{NO}_{2}$ on aerosol produces a considerable portion of HONO in relatively polluted months (December-May), but contributes very little in clean months (June-October), as seen in Sect. 3.3.3. Coincidentally, direct emissions from burning processes of HONO decrease from their peak values from winter to summer (Sect. 3.2). However, the monthly averaged ratios of HONO to $\mathrm{NO}_{x}$ are highest in summer, which conflicts with the two sources mentioned above.

As is known, a higher $\mathrm{NO}_{2}$-to-HONO conversion level or other $\mathrm{NO}_{x}$-independent sources can cause an increase in the $\mathrm{HONO} / \mathrm{NO}_{x}$ ratio. For the case of a mostly constant surface with low reactivity due to the prolonged exposure to oxidizing gases and radiation, the yield of nighttime $\mathrm{HONO}$ from $\mathrm{NO}_{2}$ reacting on ground surfaces could be imprecisely assumed to be unchanged. Thus, soil nitrite formed through microbial activities, especially nitrification by ammonia-oxidizing bacteria $\left(\mathrm{NH}_{4}^{+} \rightarrow \mathrm{NO}_{2}^{-}\right.$) ( $\mathrm{Su}$ et al., 2011; Oswald et al., 2013), is adopted to be a source of atmospheric HONO in this study, considering the nearby presence of some grassland and natural vegetation mosaics. Although we do not directly measure HONO emissions from soil, the observed ammonia can represent its monthly average intensity indirectly, based on the following hypothesis: the dominant source of $\mathrm{NH}_{3}$ is from soil, especially from fertilizers $\left(\mathrm{NH}_{4}^{+} \rightarrow \mathrm{NH}_{3}\right)$, for a good correlation between ammonia and temperature in the site $(r=0.63, p=0.01)$, omitting the contributions of livestock to $\mathrm{NH}_{3}$ since there is only a small poultry facility within $10 \mathrm{~km}$ of this site (Meng et al., 2011; Huang et al., 2012; Behera et al., 2013). Combustion sources (vehicles, industry, biomass burning) should contribute only a fraction of $\mathrm{NH}_{3}$ seeing that $\mathrm{NH}_{3}$ is not related to $\mathrm{NO}_{x}$ or $\mathrm{CO}$ in our study. Moreover, the releases of both HONO and $\mathrm{NH}_{3}$ depend on the strength of microbial activities, fertilizing amount, and soil properties (e.g., temperature, acidity and water content of soil). Although the processes of HONO and $\mathrm{NH}_{3}$ emission from soil may not be completely synchronized, the seasonal patterns for each should be consistent.

Until now, we have been able to separate the sources of HONO into four parts: (1) the combustion emissions from vehicles and industries $\left(\mathrm{HONO}_{\mathrm{emi}}\right)$ with a constant emitted $\mathrm{HONO} / \mathrm{NO}_{x}$ ratio of $0.79 \%$; (2) the conversion of $\mathrm{NO}_{2}$ to $\mathrm{HONO}$ on the ground surfaces $\left(\mathrm{HONO}_{\mathrm{grd}}\right)$ with a constant but unknown yield $x_{1}$; (3) the conversion of $\mathrm{NO}_{2}$ to $\mathrm{HONO}$ on aerosol surfaces $\left(\mathrm{HONO}_{\text {aer }}\right)$ with a $\mathrm{PM}_{2.5}$-dependent yield $\left(\mathrm{HONO}_{\mathrm{aer}} / \mathrm{NO}_{2}\right)$; and (4) the emission from soil $\left(\mathrm{HONO}_{\text {soi }}\right)$, expressed by corrected $\mathrm{NH}_{3}$ multiplied by an unknown coefficient $x_{2}$. The corrected $\mathrm{NH}_{3}$ is obtained by subtracting combustion emission from total observed ammonia. Ammonia from combustion is found to be proportional to simultaneous CO (Meng et al., 2011; Chang et al., 2016), and a proportion 

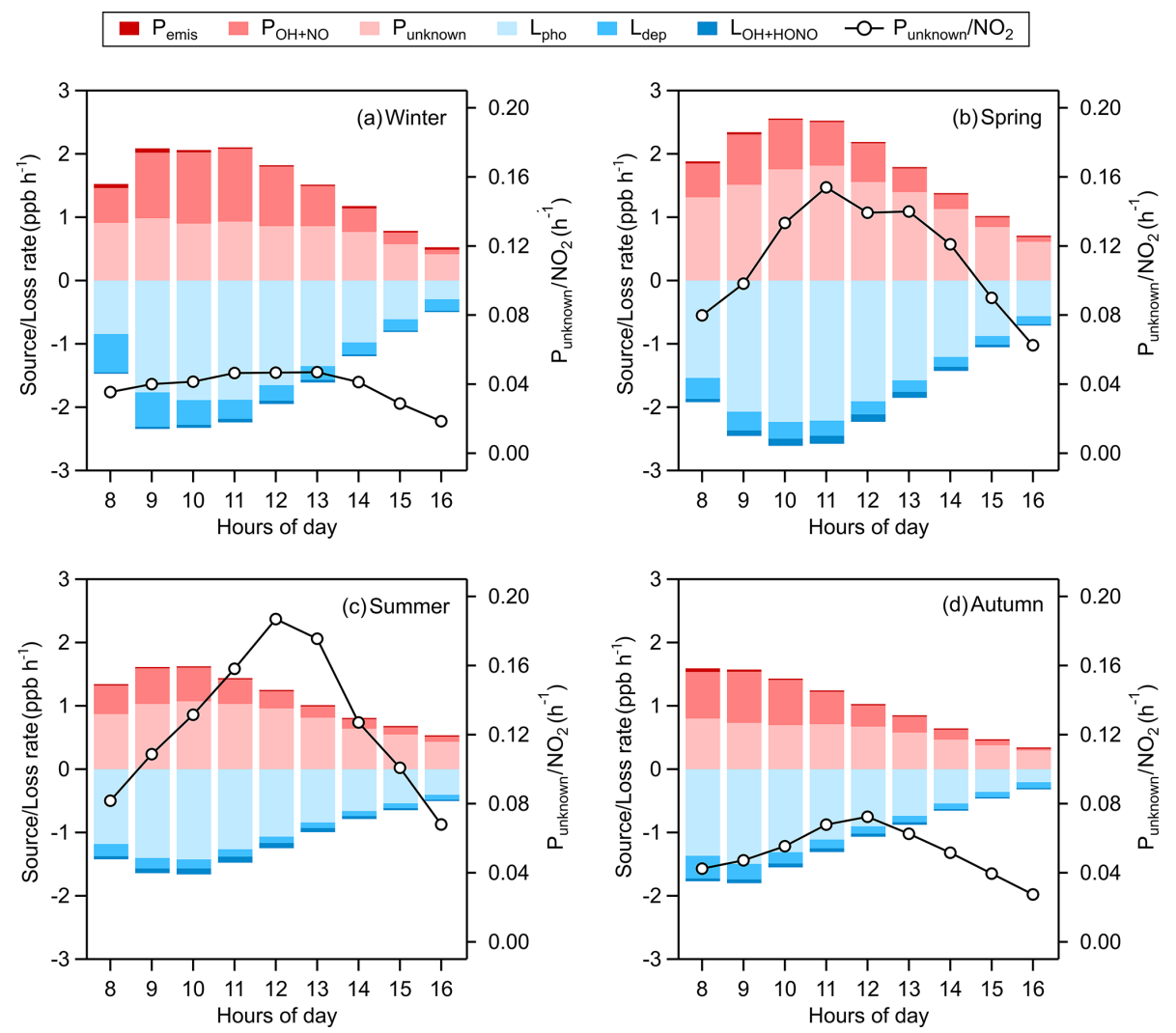

Figure 8. Averaged daytime HONO budgets and the missing source strength $\left(P_{\text {unknown }}\right)$ normalized by $\mathrm{NO}_{2}$ in (a) winter, $(\mathbf{b})$ spring, (c) summer, and (d) autumn. The mean values of $P_{\text {unknown }}$ around noontime (10:00-14:00 LT) are $0.91 \mathrm{ppb} \mathrm{h}^{-1}$ in winter, $1.61 \mathrm{ppbh}^{-1}$ in spring, $0.98 \mathrm{ppb} \mathrm{h}^{-1}$ in summer, and $0.68 \mathrm{ppb} \mathrm{h}^{-1}$ in autumn.

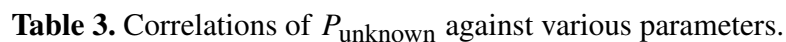

\begin{tabular}{|c|c|c|c|c|c|c|c|c|}
\hline \multirow[t]{2}{*}{ Parameters } & \multicolumn{2}{|c|}{ Winter } & \multicolumn{2}{|c|}{ Spring } & \multicolumn{2}{|c|}{ Summer } & \multicolumn{2}{|c|}{ Autumn } \\
\hline & $r$ & $N$ & $r$ & $N$ & $r$ & $N$ & $r$ & $N$ \\
\hline $\mathrm{NO}_{2}$ & 0.46 & 220 & 0.33 & 280 & 0.07 & 366 & 0.15 & 348 \\
\hline $\mathrm{PM}_{2.5}$ & 0.41 & 220 & 0.43 & 280 & 0.22 & 366 & 0.26 & 348 \\
\hline $\mathrm{NO}_{3}^{-}$ & 0.39 & 211 & 0.41 & 270 & -0.01 & 353 & 0.19 & 344 \\
\hline $\mathrm{SO}_{4}^{2-}$ & 0.34 & 204 & 0.26 & 270 & 0.15 & 357 & 0.23 & 337 \\
\hline $\mathrm{NH}_{4}^{+}$ & 0.38 & 211 & 0.36 & 273 & 0.09 & 360 & 0.22 & 332 \\
\hline $\mathrm{RH}^{4}$ & 0.00 & 220 & -0.33 & 280 & -0.37 & 366 & -0.19 & 348 \\
\hline UVB & 0.22 & 220 & 0.44 & 280 & 0.43 & 366 & 0.45 & 348 \\
\hline $\mathrm{NO}_{2} \times \mathrm{PM}_{2.5}$ & 0.42 & 220 & 0.43 & 280 & 0.10 & 366 & 0.23 & 348 \\
\hline $\mathrm{NO}_{2} \times \mathrm{NO}_{3}^{-}$ & 0.40 & 211 & 0.43 & 270 & -0.04 & 353 & 0.20 & 344 \\
\hline $\mathrm{NO}_{2} \times \mathrm{SO}_{4}^{2-}$ & 0.41 & 204 & 0.35 & 270 & 0.08 & 357 & 0.22 & 337 \\
\hline $\mathrm{NO}_{2} \times \mathrm{NH}_{4}^{+}$ & 0.41 & 211 & 0.41 & 273 & 0.05 & 360 & 0.21 & 332 \\
\hline $\mathrm{UVB} \times \mathrm{NO}_{2}$ & 0.59 & 220 & 0.68 & 280 & 0.49 & 366 & 0.65 & 348 \\
\hline $\mathrm{UVB} \times \mathrm{PM}_{2.5}$ & 0.53 & 220 & 0.64 & 280 & 0.51 & 366 & 0.65 & 348 \\
\hline $\mathrm{UVB} \times \mathrm{NO}_{3}^{-}$ & 0.50 & 211 & 0.56 & 270 & 0.25 & 353 & 0.46 & 344 \\
\hline $\mathrm{UVB} \times \mathrm{SO}_{4}^{2-}$ & 0.42 & 204 & 0.49 & 270 & 0.42 & 357 & 0.55 & 337 \\
\hline $\mathrm{UVB} \times \mathrm{NH}_{4}^{+}$ & 0.47 & 211 & 0.53 & 273 & 0.35 & 360 & 0.52 & 332 \\
\hline $\mathrm{NO}_{2} \times \mathrm{UVB} \times \mathrm{PM}_{2.5}$ & 0.53 & 220 & 0.64 & 280 & 0.39 & 366 & 0.55 & 348 \\
\hline
\end{tabular}




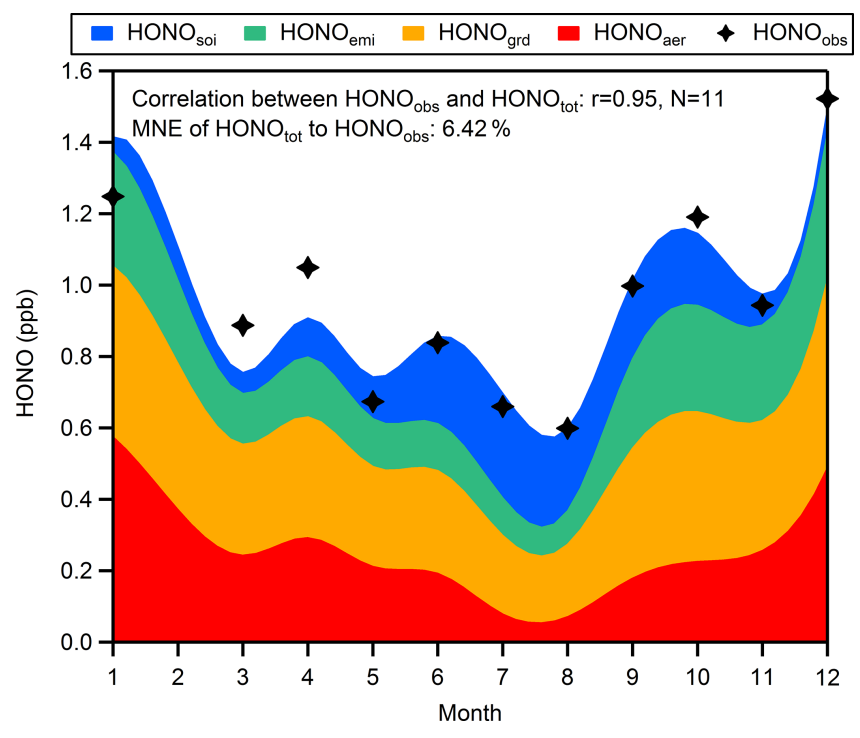

Figure 9. Seasonal variations of four sources of HONO at night (03:00-06:00 LT). The mean normalized error (MNE) of $\mathrm{HONO}_{\text {tot }}$ to $\mathrm{HONO}_{\mathrm{obs}}$ is $6.42 \%$.

of $0.3 \%$, which is in the lower quantile of the $\mathrm{NH}_{3} / \mathrm{CO}$ ratios in fresh air masses (for hourly data: $\mathrm{NO} / \mathrm{NO}_{x}>0.75$; $\mathrm{UVB}=$ 0 ; temperature $<5 \mathrm{C}^{\circ}$ ), is used from our measurements. Substituting monthly average values of measured $\mathrm{HONO}, \mathrm{NO}_{2}$, $\mathrm{PM}_{2.5}, \mathrm{NH}_{3}$, and $\mathrm{CO}$ into Eq. (11) by assuming that $\mathrm{HONO}_{\text {tot }}$ is equal to $\mathrm{HONO}_{\mathrm{obs}}$, we can get an overdetermined system of equations which has 11 equations with two unknowns (excluding mean values of related parameters from February), and then we derive an approximate solution $\left(x_{1}=1.89 \%\right.$, $x_{2}=1.62 \%$ ) by the method of ordinary least squares.

Figure 9 shows that an average of $36 \%$ of HONO is produced heterogeneously on ground surfaces without perceptible temporal variations, but the contribution of this source is overtaken by $\mathrm{NO}_{2}$ converting to $\mathrm{HONO}$ on aerosols in January (approximately $40 \%$ of HONO) and is exceeded by soil emission in July and August (approximately $40 \%$ of HONO). The seasonal variations of HONO from different pathways at night indicate that short-term observations may just capture a small part of the total picture when exploring the source mechanisms of HONO. The total HONO concentration $\left(\mathrm{HONO}_{\mathrm{tot}}\right)$ is the sum of derived HONO from the four sources listed above. The good correlation between $\mathrm{HONO}_{\text {tot }}$ and $\mathrm{HONO}_{\text {obs }}$ and the low mean normalized error of $\mathrm{HONO}_{\text {tot }}$ to $\mathrm{HONO}_{\text {obs }}$ reveal that our assumption about nocturnal HONO sources is reasonable. It should be noted that the slope of the linearly fitted line between $\mathrm{HONO}_{\text {corr }} / \mathrm{NO}_{2}$ and $\mathrm{PM}_{2.5}$ in spring $(r=0.74$, slope $=0.68 \%$ is much higher than that in winter $(r=0.60$, slope $=0.20 \%$ ), but we just use a mean slope of $0.26 \%$ o to evaluate aerosol effects throughout the year: this may be why our method underestimates HONO in March and April and overestimates HONO in January, indicating that the mass concentration of $\mathrm{PM}_{2.5}$ is not the only factor affecting formation of HONO on aerosols. Besides, lacking considerations of the impact of $\mathrm{RH}$ and temperature on $\mathrm{NO}_{2}$-to-HONO conversion and of seasonal variations in ground surface properties, uncertainties of $\mathrm{NO}_{2}$-to-HONO conversion mechanisms and of combustion HONO emissions, and lacking direct observation for soil-emitted HONO could all result in the bias between $\mathrm{HONO}_{\text {tot }}$ and $\mathrm{HONO}_{\mathrm{obs}}$, so more studies on the detailed mechanism of various HONO sources need to be performed.

$$
\begin{aligned}
& \frac{\left[\mathrm{HONO}_{\mathrm{grd}}\right]}{\left[\mathrm{NO}_{2}\right]}=x_{1} \\
& \frac{\left[\mathrm{HONO}_{\mathrm{aer}}\right]}{\left[\mathrm{NO}_{2}\right]}=0.26 \% \circ \times\left[\mathrm{PM}_{2.5}\right] \\
& \frac{\left[\mathrm{HONO}_{\mathrm{emi}}\right]}{\left[\mathrm{NO}_{x}\right]}=0.79 \% \\
& \left.\frac{[\mathrm{HONO}}{\mathrm{soi}]}\right] \\
& {\left[\mathrm{NH}_{3}\right]-0.3 \% \times[\mathrm{CO}]} \\
& {\left[\mathrm{HONO}_{\mathrm{tot}}\right]=\left[\mathrm{HONO} \mathrm{emi}_{2}\right]+\left[\mathrm{HONO}_{\mathrm{soi}}\right]} \\
& +\left[\mathrm{HONO}_{\mathrm{grd}}\right]+\left[\mathrm{HONO}_{\mathrm{aer}}\right]
\end{aligned}
$$

\section{Conclusions}

Continuous field measurement of HONO over 1 year was conducted at the SORPES station in Nanjing in the western YRD of China, from December 2017 to December 2018. The observed seasonal average concentrations of HONO are in the range of $0.45-1.04 \mathrm{ppb}$, which are comparable to those in other urban or suburban regions and appear to be of vital importance to atmospheric oxidation as the $\mathrm{OH}$ production rate of HONO is almost 3 times as that of ozone at daytime. $\mathrm{HONO}$ and $\mathrm{NO}_{x}$ have coincident monthly variations peaking in December and decreasing to the lowest value in August and have similar diurnal pattern with the highest value in the early morning and a low point in the late afternoon, both indicating that $\mathrm{NO}_{x}$ is a crucial precursor of HONO.

Combustion emissions contribute an average of $23 \%$ to nocturnal HONO concentrations, with an average emission ratio $\mathrm{HONO} / \mathrm{NO}_{x}$ of $0.79 \%$. During the nighttime, the dominant source of RH-dependent HONO could be the heterogeneous reaction of $\mathrm{NO}_{2}$ on wet ground or aerosol surfaces with a mean estimated conversion rate of $0.0055 \mathrm{~h}^{-1}$. During the daytime, a missing HONO source with an average strength of $1.04 \mathrm{ppbh}^{-1}$ was identified around noon, contributing about $61 \%$ of the production of HONO and seeming to be photo-enhanced. HONO released from soil is adopted to discuss the seasonal changes in nocturnal HONO and can contribute $40 \%$ to HONO during summer. Ground formation provides a major part of $\mathrm{HONO}$ at a roughly constant proportion of $36 \%$. The uptake of $\mathrm{NO}_{2}$ on aerosol surface can generate the greatest amount of HONO during heavily polluted periods (e.g., January). Our results draw a complete picture of the sources of HONO during different sea- 
sons and demonstrated the needs of long-term and comprehensive observations to improve the understanding of $\mathrm{HONO}$ chemistry.

Data availability. Measurement data at the SORPES station, including HONO data and relevant trace gases and aerosol data as well as meteorological data, are available upon request from the corresponding author before the SORPES database is open to the public. The total column ozone data are available at https://doi.org/10.5067/Aura/OMI/DATA3002 (Bhartia, 2012).

Supplement. The supplement related to this article is available online at: https://doi.org/10.5194/acp-19-13289-2019-supplement.

Author contributions. WN and AD designed the study; YL and WN wrote the manuscript; YL, ZX and RX collected the HONO data and contributed to the data analysis; TW, YL, LW and XC collected other related data, e.g., $\mathrm{NH}_{3}, \mathrm{NO}_{x}$ and $\mathrm{PM}_{2.5}$.

Competing interests. The authors declare that they have no conflict of interest.

Acknowledgements. We thank colleagues and students at the School of Atmospheric Sciences at Nanjing University for their contributions to the maintenance of the measurements.

Financial support. This work was mainly funded by the National Key R\&D Program of China (grant nos. 2016YFC0202000 and 2016YFC0200500), the National Natural Science Foundation of China (NSFC) project (grant nos. D0512/41675145 and D0510/41605098), and the Jiangsu Provincial Science Fund (grant no. BK20160620). Data analysis was also supported by other NSFC projects (grant nos. D0512/41875175 and D0510/91644218).

Review statement. This paper was edited by Jianzhong Ma and reviewed by three anonymous referees.

\section{References}

Acker, K., Febo, A., Trick, S., Perrino, C., Bruno, P., Wiesen, P., Möller, D., Wieprecht, W., Auel, R., and Giusto, M.: Nitrous acid in the urban area of Rome, Atmos. Environ., 40, 3123-3133, 2006.

Ackermann, R.: Auswirkungen von Kraftfahrzeugemissionen in der urbanen Atmosphäre, Dissertation, Germany, 2000.

Alicke, B.: Impact of nitrous acid photolysis on the total hydroxyl radical budget during the Limitation of Oxidant Production/Pianura Padana Produzione di Ozono study in Milan, J. Geophys. Res., 107, 8196, https://doi.org/10.1029/2000jd000075, 2002.
Alicke, B.: $\mathrm{OH}$ formation by HONO photolysis during the BERLIOZ experiment, J. Geophys. Res., 108, 8247, https://doi.org/10.1029/2001jd000579, 2003.

Alicke, B., Platt, U., and Stutz, J.: Impact of nitrous acid photolysis on the total hydroxyl radical budget during the Limitation of Oxidant Production/Pianura Padana Produzione di Ozono study in Milan, J. Geophys. Res.-Atmos., 107, LOP 9-1-LOP 9-17, https://doi.org/10.1029/2000JD000075, 2002.

Ammann, M., Kalberer, M., Jost, D., Tobler, L., Rossler, E., Piguet, D., Gaggeler, H., and Baltensperger, U.: Heterogeneous production of nitrous acid on soot in polluted airmasses, Nature, 395 157-160, https://doi.org/10.1038/25965, 1998.

Ammann, M., Rossler, E., Strekowski, R., and George, C.: Nitrogen dioxide multiphase chemistry: uptake kinetics on aqueous solutions containing phenolic compounds, Phys. Chem. Chem. Phys., 7, 2513-2518, https://doi.org/10.1039/b501808k, 2005.

Atkinson, R.: Atmospheric chemistry of VOCs and $\mathrm{NO}_{x}$, Atmos. Environ., 34, 2063-2101, 2000.

Atkinson, R., Baulch, D. L., Cox, R. A., Crowley, J. N., Hampson, R. F., Hynes, R. G., Jenkin, M. E., Rossi, M. J., and Troe, J.: Evaluated kinetic and photochemical data for atmospheric chemistry: Volume $\mathrm{I}-$ gas phase reactions of $\mathrm{O}_{\mathrm{x}}, \mathrm{HO}_{\mathrm{x}}$, $\mathrm{NO}_{\mathrm{x}}$ and $\mathrm{SO}_{\mathrm{x}}$ species, Atmos. Chem. Phys., 4, 1461-1738, https://doi.org/10.5194/acp-4-1461-2004, 2004.

Aubin, D. G. and Abbatt, J. P.: Interaction of $\mathrm{NO}_{2}$ with hydrocarbon soot: Focus on HONO yield, surface modification, and mechanism, J. Phys. Chem. A, 111, 6263-6273, 2007.

Bhartia, P. K.: OMI/Aura TOMS-Like Ozone and Radiative Cloud Fraction L3 1 day 0.25 degree $\times 0.25$ degree V3, NASA Goddard Space Flight Center, Goddard Earth Sciences Data and Information Services Center (GES DISC), https://doi.org/10.5067/Aura/OMI/DATA3002, 2012.

Behera, S. N., Sharma, M., Aneja, V. P., and Balasubramanian, R.: Ammonia in the atmosphere: a review on emission sources, atmospheric chemistry and deposition on terrestrial bodies, Environ. Sci. Pollut. R., 20, 8092-8131, https://doi.org/10.1007/s11356-013-2051-9, 2013.

Bernard, F., Cazaunau, M., Grosselin, B., Zhou, B., Zheng, J., Liang, P., Zhang, Y., Ye, X., Daele, V., Mu, Y., Zhang, R., Chen, J., and Mellouki, A.: Measurements of nitrous acid (HONO) in urban area of Shanghai, China, Environ. Sci. Pollut. R., 23, 5818-5829, https://doi.org/10.1007/s11356-015-5797-4, 2016.

Canfield, D. E., Glazer, A. N., and Falkowski, P. G.: The Evolution and Future of Earth's Nitrogen Cycle, Science, 330, 192-196, https://doi.org/10.1126/science.1186120, 2010.

Chang, Y., Zou, Z., Deng, C., Huang, K., Collett, J. L., Lin, J., and Zhuang, G.: The importance of vehicle emissions as a source of atmospheric ammonia in the megacity of Shanghai, Atmos. Chem. Phys., 16, 3577-3594, https://doi.org/10.5194/acp16-3577-2016, 2016.

Coe, $\mathrm{H}$. and Gallagher, M.: Measurements of dry deposition of $\mathrm{NO}_{2}$ to a Dutch heathland using the eddy-correlation technique, Q. J. Roy. Meteor. Soc., 118, 767-786, 1992.

Cui, L., Li, R., Zhang, Y., Meng, Y., Fu, H., and Chen, J.: An observational study of nitrous acid (HONO) in Shanghai, China: The aerosol impact on HONO formation during the haze episodes, Sci. Total Environ., 630, 1057-1070, https://doi.org/10.1016/j.scitotenv.2018.02.063, 2018. 
Dillon, M. B., Lamanna, M. S., Schade, G. W., Goldstein, A. H., and Cohen, R. C.: Chemical evolution of the Sacramento urban plume: Transport and oxidation, J. Geophys. Res.-Atmos., 107, ACH 3-1-ACH 3-15, https://doi.org/10.1029/2001jd000969, 2002.

Ding, A., Nie, W., Huang, X., Chi, X., Sun, J., Kerminen, V.-M., Xu, Z., Guo, W., Petäjä, T., Yang, X., Kulmala, M., and Fu, C.: Longterm observation of air pollution-weather/climate interactions at the SORPES station: a review and outlook, Front. Env. Sci. Eng., 10, 15, https://doi.org/10.1007/s11783-016-0877-3, 2016.

Ding, A. J., Fu, C. B., Yang, X. Q., Sun, J. N., Zheng, L. F., Xie, Y. N., Herrmann, E., Nie, W., Petäjä, T., Kerminen, V.-M., and Kulmala, M.: Ozone and fine particle in the western Yangtze River Delta: an overview of 1 yr data at the SORPES station, Atmos. Chem. Phys., 13, 5813-5830, https://doi.org/10.5194/acp13-5813-2013, 2013.

Dusanter, S., Vimal, D., Stevens, P. S., Volkamer, R., and Molina, L. T.: Measurements of $\mathrm{OH}$ and $\mathrm{HO}_{2}$ concentrations during the MCMA-2006 field campaign - Part 1: Deployment of the Indiana University laser-induced fluorescence instrument, Atmos. Chem. Phys., 9, 1665-1685, https://doi.org/10.5194/acp-9-16652009, 2009.

Elshorbany, Y. F., Kurtenbach, R., Wiesen, P., Lissi, E., Rubio, M., Villena, G., Gramsch, E., Rickard, A. R., Pilling, M. J., and Kleffmann, J.: Oxidation capacity of the city air of Santiago, Chile, Atmos. Chem. Phys., 9, 2257-2273, https://doi.org/10.5194/acp9-2257-2009, 2009.

Finlayson-Pitts, B. J. and Pitts, J. N.: CHAPTER 6 - Rates and Mechanisms of Gas-Phase Reactions in Irradiated Organic $\mathrm{NO}_{x}$ - Air Mixtures, in: Chemistry of the Upper and Lower Atmosphere, edited by: Finlayson-Pitts, B. J., and Pitts, J. N., Academic Press, San Diego, 179-263, 2000.

Finlayson-Pitts, B. J., Wingen, L. M., Sumner, A. L., Syomin, D., and Ramazan, K. A.: The heterogeneous hydrolysis of $\mathrm{NO}_{2}$ in laboratory systems and in outdoor and indoor atmospheres: An integrated mechanism, Phys. Chem. Chem. Phys., 5, 223-242, https://doi.org/10.1039/b208564j, 2003.

Fountoukis, C. and Nenes, A.: ISORROPIA II: a computationally efficient thermodynamic equilibrium model for $\mathrm{K}^{+}-\mathrm{Ca}_{2}^{+}-\mathrm{Mg}_{2}^{+}-$ $\mathrm{NH}_{4}^{+}-\mathrm{Na}^{+}-\mathrm{SO}_{4}^{2-}-\mathrm{NO}_{3}^{-}-\mathrm{Cl}^{-}-\mathrm{H}_{2} \mathrm{O}$ aerosols, Atmos. Chem. Phys., 7, 4639-4659, https://doi.org/10.5194/acp-7-4639-2007, 2007.

George, C., Strekowski, R. S., Kleffmann, J., Stemmler, K., and Ammann, M.: Photoenhanced uptake of gaseous $\mathrm{NO}_{2}$ on solid organic compounds: a photochemical source of HONO?, Faraday Discuss., 130, 195-210, https://doi.org/10.1039/b417888m, 2005.

Grassian, V.: Chemical reactions of nitrogen oxides on the surface of oxide, carbonate, soot, and mineral dust particles: Implications for the chemical balance of the troposphere, J. Phys. Chem. A, 106, 860-877, 2002.

Han, C., Liu, Y., and He, H.: Heterogeneous reaction of $\mathrm{NO}_{2}$ with soot at different relative humidity, Environ. Sci. Pollut. R., 24, 21248-21255, https://doi.org/10.1007/s11356-017-9766$\mathrm{y}, 2017$.

Hao, N., Zhou, B., Chen, D., and Chen, L.-M.: Observations of nitrous acid and its relative humidity dependence in Shanghai, J. Environ. Sci., 18, 910-915, https://doi.org/10.1016/s10010742(06)60013-2, 2006.
Harrison, R. M., Peak, J. D., and Collins, G. M.: Tropospheric cycle of nitrous acid, J. Geophys. Res.-Atmos., 101, 14429-14439, 1996.

Heland, J., Kleefmann, J., Kurtenbach, R., and Wiesen, P.: A new instrument to measure gaseous nitrous acid (HONO) in the atmosphere, Environ. Sci. Technol., 35, 3207-3212, 2001.

Hendrick, F., Müller, J.-F., Clémer, K., Wang, P., De Mazière, M., Fayt, C., Gielen, C., Hermans, C., Ma, J. Z., Pinardi, G., Stavrakou, T., Vlemmix, T., and Van Roozendael, M.: Four years of ground-based MAX-DOAS observations of HONO and $\mathrm{NO}_{2}$ in the Beijing area, Atmos. Chem. Phys., 14, 765-781, https://doi.org/10.5194/acp-14-765-2014, 2014.

Herrmann, H., Schaefer, T., Tilgner, A., Styler, S. A., Weller, C., Teich, M., and Otto, T.: Tropospheric aqueousphase chemistry: kinetics, mechanisms, and its coupling to a changing gas phase, Chem. Rev., 115, 4259-4334, https://doi.org/10.1021/cr500447k, 2015.

Hou, S., Tong, S., Ge, M., and An, J.: Comparison of atmospheric nitrous acid during severe haze and clean periods in Beijing, China, Atmos. Environ., 124, 199-206, https://doi.org/10.1016/j.atmosenv.2015.06.023, 2016.

Huang, R. J., Yang, L., Cao, J., Wang, Q., Tie, X., Ho, K. F., Shen, Z., Zhang, R., Li, G., Zhu, C., Zhang, N., Dai, W., Zhou, J., Liu, S., Chen, Y., Chen, J., and O'Dowd, C. D.: Concentration and sources of atmospheric nitrous acid (HONO) at an urban site in Western China, Sci. Total Environ., 593-594, 165-172, https://doi.org/10.1016/j.scitotenv.2017.02.166, 2017.

Huang, X., Song, Y., Li, M., Li, J., Huo, Q., Cai, X., Zhu, T., Hu, M., and Zhang, H.: A high-resolution ammonia emission inventory in China, Global Biogeochem. Cy., 26, GB1030, https://doi.org/10.1029/2011gb004161, 2012.

Jarvis, D. L., Leaderer, B. P., Chinn, S., and Burney, P. G.: Indoor nitrous acid and respiratory symptoms and lung function in adults, Thorax, 60, 474-479, https://doi.org/10.1136/thx.2004.032177, 2005.

Jenkin, M. E., Cox, R. A., and Williams, D. J.: Laboratory studies of the kinetics of formation of nitrous acid from the thermal reaction of nitrogen dioxide and water vapour, Atmos. Environ., 22, 487498, 1988.

Kalberer, M., Ammann, M., Arens, F., Gäggeler, H. W., and Baltensperger, U.: Heterogeneous formation of nitrous acid (HONO) on soot aerosol particles, J. Geophys. Res.-Atmos., 104, 1382513832, https://doi.org/10.1029/1999jd900141, 1999.

Kanaya, Y., Cao, R., Akimoto, H., Fukuda, M., Komazaki, Y., Yokouchi, Y., Koike, M., Tanimoto, H., Takegawa, N., and Kondo, Y.: Urban photochemistry in central Tokyo: 1. Observed and modeled $\mathrm{OH}$ and $\mathrm{HO}_{2}$ radical concentrations during the winter and summer of 2004, J. Geophys. Res., 112, D21312, https://doi.org/10.1029/2007jd008670, 2007.

Khalizov, A. F., Cruz-Quinones, M., and Zhang, R.: Heterogeneous reaction of $\mathrm{NO}_{2}$ on fresh and coated soot surfaces, J. Phys. Chem. A, 114, 7516-7524, 2010.

Kirchner, U., Scheer, V., and Vogt, R.: FTIR spectroscopic investigation of the mechanism and kinetics of the heterogeneous reactions of $\mathrm{NO}_{2}$ and $\mathrm{HNO}_{3}$ with soot, J. Phys. Chem. A, 104, 8908-8915, 2000.

Kirchstetter, T., Harley, R., and Littlejohn, D.: Measurement of Nitrous Acid in Motor Vehicle Exhaust, Environ. Sci. Tech. Lett., 30, 2843-2849, https://doi.org/10.1021/es960135y, 1996. 
Kleffmann, J., Becker, K., and Wiesen, P.: Heterogeneous NO2 conversion processes on acid surfaces: Possible atmospheric implications, Atmos. Environ., 32, 2721-2729, https://doi.org/10.1016/S1352-2310(98)00065-X, 1998.

Kleffmann, J., Becker, K. H., Lackhoff, M., and Wiesen, P.: Heterogeneous conversion of $\mathrm{NO}_{2}$ on carbonaceous surfaces, Phys. Chem. Chem. Phys., 1, 5443-5450, 1999.

Kleffmann, J.: Daytime formation of nitrous acid: A major source of OH radicals in a forest, Geophys. Res. Lett., 32, L05818, https://doi.org/10.1029/2005g1022524, 2005.

Kleffmann, J., Lörzer, J. C., Wiesen, P., Kern, C., Trick, S., Volkamer, R., Rodenas, M., and Wirtz, K.: Intercomparison of the DOAS and LOPAP techniques for the detection of nitrous acid (HONO), Atmos. Environ., 40, 3640-3652, https://doi.org/10.1016/j.atmosenv.2006.03.027, 2006.

Kurtenbach, R., Becker, K., Gomes, J., Kleffmann, J., Lorzer, J., Spittler, M., Wiesen, P., Ackermann, R., Geyer, A., and Platt, U.: Investigations of emissions and heterogeneous formation of HONO in a road traffic tunnel, Atmos. Environ., 35, 3385-3394, https://doi.org/10.1016/S1352-2310(01)00138-8, 2001.

Lammel, G.: Formation of nitrous acid: parameterisation and comparison with observations, Max-Planck-Institut für Meteorologie, 1999.

Lammel, G. and Cape, J. N.: Nitrous Acid and Nitrite in the Atmosphere, Chem. Soc. Rev., 25, 361-369, https://doi.org/10.1039/cs9962500361, 1996.

Lee, J. D., Whalley, L. K., Heard, D. E., Stone, D., Dunmore, R. E., Hamilton, J. F., Young, D. E., Allan, J. D., Laufs, S., and Kleffmann, J.: Detailed budget analysis of HONO in central London reveals a missing daytime source, Atmos. Chem. Phys., 16, 2747-2764, https://doi.org/10.5194/acp-16-2747-2016, 2016.

Li, D., Xue, L., Wen, L., Wang, X., Chen, T., Mellouki, A., Chen, J., and Wang, W.: Characteristics and sources of nitrous acid in an urban atmosphere of northern China: Results from 1-yr continuous observations, Atmos. Environ., 182, 296-306, https://doi.org/10.1016/j.atmosenv.2018.03.033, 2018.

Li, X., Brauers, T., Häseler, R., Bohn, B., Fuchs, H., Hofzumahaus, A., Holland, F., Lou, S., Lu, K. D., Rohrer, F., Hu, M., Zeng, L. M., Zhang, Y. H., Garland, R. M., Su, H., Nowak, A., Wiedensohler, A., Takegawa, N., Shao, M., and Wahner, A.: Exploring the atmospheric chemistry of nitrous acid (HONO) at a rural site in Southern China, Atmos. Chem. Phys., 12, 1497-1513, https://doi.org/10.5194/acp-12-1497-2012, 2012.

Li, X., Rohrer, F., Hofzumahaus, A., Brauers, T., Haseler, R., Bohn, B., Broch, S., Fuchs, H., Gomm, S., Holland, F., Jager, J., Kaiser, J., Keutsch, F. N., Lohse, I., Lu, K. D., Tillmann, R., Wegener, R., Wolfe, G. M., Mentel, T. F., Kiendler-Scharr, A., and Wahner, A.: Missing Gas-Phase Source of HONO Inferred from Zeppelin Measurements in the Troposphere, Science, 344, 292-296, https://doi.org/10.1126/science.1248999, 2014.

Lu, K. D., Rohrer, F., Holland, F., Fuchs, H., Bohn, B., Brauers, T., Chang, C. C., Häseler, R., Hu, M., Kita, K., Kondo, Y., Li, X., Lou, S. R., Nehr, S., Shao, M., Zeng, L. M., Wahner, A., Zhang, Y. H., and Hofzumahaus, A.: Observation and modelling of $\mathrm{OH}$ and $\mathrm{HO}_{2}$ concentrations in the Pearl River Delta 2006: a missing $\mathrm{OH}$ source in a VOC rich atmosphere, Atmos. Chem. Phys., 12, 1541-1569, https://doi.org/10.5194/acp-12-1541-2012, 2012.

Lu, K. D., Hofzumahaus, A., Holland, F., Bohn, B., Brauers, T., Fuchs, H., Hu, M., Häseler, R., Kita, K., Kondo, Y., Li, X., Lou,
S. R., Oebel, A., Shao, M., Zeng, L. M., Wahner, A., Zhu, T., Zhang, Y. H., and Rohrer, F.: Missing OH source in a suburban environment near Beijing: observed and modelled $\mathrm{OH}$ and $\mathrm{HO}_{2}$ concentrations in summer 2006, Atmos. Chem. Phys., 13, 1057 1080, https://doi.org/10.5194/acp-13-1057-2013, 2013.

Meng, X.-L., Rosenthal, R., and Rubin, D. B.: Comparing correlated correlation coefficients, Psychol. Bull., 111, 172-175, https://doi.org/10.1037/0033-2909.111.1.172, 1992.

Meng, Z. Y., Lin, W. L., Jiang, X. M., Yan, P., Wang, Y., Zhang, Y. M., Jia, X. F., and Yu, X. L.: Characteristics of atmospheric ammonia over Beijing, China, Atmos. Chem. Phys., 11, 6139_ 6151, https://doi.org/10.5194/acp-11-6139-2011, 2011.

Meusel, H., Kuhn, U., Reiffs, A., Mallik, C., Harder, H., Martinez, M., Schuladen, J., Bohn, B., Parchatka, U., Crowley, J. N., Fischer, H., Tomsche, L., Novelli, A., Hoffmann, T., Janssen, R. H. H., Hartogensis, O., Pikridas, M., Vrekoussis, M., Bourtsoukidis, E., Weber, B., Lelieveld, J., Williams, J., Pöschl, U., Cheng, Y., and $\mathrm{Su}, \mathrm{H}$.: Daytime formation of nitrous acid at a coastal remote site in Cyprus indicating a common ground source of atmospheric HONO and NO, Atmos. Chem. Phys., 16, 14475-14493, https://doi.org/10.5194/acp-16-14475-2016, 2016.

Michoud, V., Colomb, A., Borbon, A., Miet, K., Beekmann, M., Camredon, M., Aumont, B., Perrier, S., Zapf, P., Siour, G., AitHelal, W., Afif, C., Kukui, A., Furger, M., Dupont, J. C., Haeffelin, M., and Doussin, J. F.: Study of the unknown HONO daytime source at a European suburban site during the MEGAPOLI summer and winter field campaigns, Atmos. Chem. Phys., 14, 2805-2822, https://doi.org/10.5194/acp-14-2805-2014, 2014.

Nie, W., Ding, A. J., Xie, Y. N., Xu, Z., Mao, H., Kerminen, V.-M., Zheng, L. F., Qi, X. M., Huang, X., Yang, X.Q., Sun, J. N., Herrmann, E., Petäjä, T., Kulmala, M., and Fu, C. B.: Influence of biomass burning plumes on HONO chemistry in eastern China, Atmos. Chem. Phys., 15, 1147-1159, https://doi.org/10.5194/acp-15-1147-2015, 2015.

Oswald, R., Behrendt, T., Ermel, M., Wu, D., Su, H., Cheng, Y., Breuninger, C., Moravek, A., Mougin, E., and Delon, C.: HONO emissions from soil bacteria as a major source of atmospheric reactive nitrogen, Science, 341, 1233-1235, 2013.

Pagsberg, P., Bjergbakke, E., Ratajczak, E., and Sillesen, A.: Kinetics of the gas phase reaction $\mathrm{OH}+\mathrm{NO}(+\mathrm{M}) \rightarrow \mathrm{HONO}(+\mathrm{M})$ and the determination of the UV absorption cross sections of HONO, Chem. Phys. Lett., 272, 383-390, https://doi.org/10.1016/s00092614(97)00576-9, 1997.

Perner, D. and Platt, U.: Detection of nitrous acid in the atmosphere by differential optical absorption, Geophys. Res. Lett., 6, 917920, https://doi.org/10.1029/GL006i012p00917, 1979.

Platt, U., Perner, D., Harris, G. W., Winer, A. M., and Pitts, J. N.: Observations of nitrous acid in an urban atmosphere by differential optical absorption, Nature, 285, 312-314, https://doi.org/10.1038/285312a0, 1980.

Qi, X. M., Ding, A. J., Nie, W., Petäjä, T., Kerminen, V.-M., Herrmann, E., Xie, Y. N., Zheng, L. F., Manninen, H., Aalto, P., Sun, J. N., Xu, Z. N., Chi, X. G., Huang, X., Boy, M., Virkkula, A., Yang, X.-Q., Fu, C. B., and Kulmala, M.: Aerosol size distribution and new particle formation in the western Yangtze River Delta of China: 2 years of measurements at the SORPES station, Atmos. Chem. Phys., 15, 12445-12464, https://doi.org/10.5194/acp-15-12445-2015, 2015. 
Rappenglück, B., Lubertino, G., Alvarez, S., Golovko, J., Czader, B., and Ackermann, L.: Radical precursors and related species from traffic as observed and modeled at an urban highway junction, J. Air Waste Manage., 63, 1270-1286, https://doi.org/10.1080/10962247.2013.822438, 2013.

Reisinger, A. R.: Observations of $\mathrm{HNO}_{2}$ in the polluted winter atmosphere: possible heterogeneous production on aerosols, Atmos. Environ., 34, 3865-3874, 2000.

Richter, A., Burrows, J. P., Nuss, H., Granier, C., and Niemeier, U.: Increase in tropospheric nitrogen dioxide over China observed from space, Nature, 437, 129-132, https://doi.org/10.1038/nature04092, 2005.

Rohde, R. A. and Muller, R. A.: Air Pollution in China: Mapping of Concentrations and Sources, PLoS One, 10, e0135749, https://doi.org/10.1371/journal.pone.0135749, 2015.

Rohrer, F. and Berresheim, H.: Strong correlation between levels of tropospheric hydroxyl radicals and solar ultraviolet radiation, Nature, 442, 184-187, https://doi.org/10.1038/nature04924, 2006.

Rohrer, F., Lu, K., Hofzumahaus, A., Bohn, B., Brauers, T., Chang, C.-C., Fuchs, H., Häseler, R., Holland, F., Hu, M., Kita, K., Kondo, Y., Li, X., Lou, S., Oebel, A., Shao, M., Zeng, L., Zhu, T., Zhang, Y., and Wahner, A.: Maximum efficiency in the hydroxylradical-based self-cleansing of the troposphere, Nat. Geosci., 7, 559-563, https://doi.org/10.1038/ngeo2199, 2014.

Saliba, N., Yang, H., and Finlayson-Pitts, B.: Reaction of gaseous nitric oxide with nitric acid on silica surfaces in the presence of water at room temperature, J. Phys. Chem. A, 105, 10339-10346, 2001.

Seinfeld, J. H. and Pandis, S. N.: Atmospheric chemistry and physics: from air pollution to climate change, John Wiley \& Sons, 2016.

Shao, P., Xin, J., An, J., Kong, L., Wang, B., Wang, J., Wang, Y., and Wu, D.: The empirical relationship between $\mathrm{PM}_{2.5}$ and AOD in Nanjing of the Yangtze River Delta, Atmos. Pollut. Res., 8, 233243, https://doi.org/10.1016/j.apr.2016.09.001, 2017.

Shen, Y., Virkkula, A., Ding, A., Wang, J., Chi, X., Nie, W., Qi, X., Huang, X., Liu, Q., Zheng, L., Xu, Z., Petäjä, T., Aalto, P. P., Fu, C., and Kulmala, M.: Aerosol optical properties at SORPES in Nanjing, east China, Atmos. Chem. Phys., 18, 5265-5292, https://doi.org/10.5194/acp-18-5265-2018, 2018.

Sleiman, M., Gundel, L. A., Pankow, J. F., Jacob III, P., Singer, B. C., and Destaillats, H.: Formation of carcinogens indoors by surface-mediated reactions of nicotine with nitrous acid, leading to potential thirdhand smoke hazards, P. Natl. Acad. Sci. USA, 107, 6576-6581, https://doi.org/10.1073/pnas.0912820107, 2010.

Sörgel, M., Regelin, E., Bozem, H., Diesch, J.-M., Drewnick, F., Fischer, H., Harder, H., Held, A., Hosaynali-Beygi, Z., Martinez, M., and Zetzsch, C.: Quantification of the unknown HONO daytime source and its relation to $\mathrm{NO}_{2}$, Atmos. Chem. Phys., 11, 10433-10447, https://doi.org/10.5194/acp-11-104332011, 2011.

Stemmler, K., Ammann, M., Donders, C., Kleffmann, J., and George, C.: Photosensitized reduction of nitrogen dioxide on humic acid as a source of nitrous acid, Nature, 440, 195-198, https://doi.org/10.1038/nature04603, 2006.

Stemmler, K., Ndour, M., Elshorbany, Y., Kleffmann, J., D’Anna, B., George, C., Bohn, B., and Ammann, M.: Light induced conversion of nitrogen dioxide into nitrous acid on submicron humic acid aerosol, Atmos. Chem. Phys., 7, 4237-4248, https://doi.org/10.5194/acp-7-4237-2007, 2007.

Stutz, J., Kim, E. S., Platt, U., Bruno, P., Perrino, C., and Febo, A.: UV-visible absorption cross sections of nitrous acid, J. Geophys. Res.-Atmos., 105, 14585-14592, https://doi.org/10.1029/2000jd900003, 2000.

Stutz, J., Alicke, B., and Neftel, A.: Nitrous acid formation in the urban atmosphere: Gradient measurements of $\mathrm{NO}_{2}$ and HONO over grass in Milan, Italy, J. Geophys. Res., 107, 8192, https://doi.org/10.1029/2001jd000390, 2002.

Stutz, J., Alicke, B., Ackermann, R., Geyer, A., Wang, S., White, A. B., Williams, E. J., Spicer, C. W., and Fast, J. D.: Relative humidity dependence of HONO chemistry in urban areas, J. Geophys. Res.-Atmos., 109, D03307, https://doi.org/10.1029/2003jd004135, 2004.

Su, H., Cheng, Y. F., Cheng, P., Zhang, Y. H., Dong, S., Zeng, L. M., Wang, X., Slanina, J., Shao, M., and Wiedensohler, A.: Observation of nighttime nitrous acid (HONO) formation at a nonurban site during PRIDE-PRD2004 in China, Atmos. Environ., 42, 6219-6232, https://doi.org/10.1016/j.atmosenv.2008.04.006, 2008a.

Su, H., Cheng, Y. F., Shao, M., Gao, D. F., Yu, Z. Y., Zeng, L. M., Slanina, J., Zhang, Y. H., and Wiedensohler, A.: Nitrous acid (HONO) and its daytime sources at a rural site during the 2004 PRIDE-PRD experiment in China, J. Geophys. Res., 113, D14312, https://doi.org/10.1029/2007jd009060, 2008 b.

Su, H., Cheng, Y., Oswald, R., Behrendt, T., Trebs, I., Meixner, F. X., Andreae, M. O., Cheng, P., Zhang, Y., and Pöschl, U.: Soil nitrite as a source of atmospheric $\mathrm{HONO}$ and $\mathrm{OH}$ radicals, Science, 333, 1616-1618, 2011.

Sumner, A. L., Menke, E. J., Dubowski, Y., Newberg, J. T., Penner, R. M., Hemminger, J. C., Wingen, L. M., Brauers, T., and Finlayson-Pitts, B. J.: The nature of water on surfaces of laboratory systems and implications for heterogeneous chemistry in the troposphere, Phys. Chem. Chem. Phys., 6, 604-613, https://doi.org/10.1039/b308125g, 2004.

Sun, P., Nie, W., Chi, X., Xie, Y., Huang, X., Xu, Z., Qi, X., Xu, Z., Wang, L., Wang, T., Zhang, Q., and Ding, A.: Two years of online measurement of fine particulate nitrate in the western Yangtze River Delta: influences of thermodynamics and $\mathrm{N}_{2} \mathrm{O}_{5}$ hydrolysis, Atmos. Chem. Phys., 18, 17177-17190, https://doi.org/10.5194/acp-18-17177-2018, 2018.

Tan, Z., Fuchs, H., Lu, K., Hofzumahaus, A., Bohn, B., Broch, S., Dong, H., Gomm, S., Häseler, R., He, L., Holland, F., Li, X., Liu, Y., Lu, S., Rohrer, F., Shao, M., Wang, B., Wang, M., Wu, Y., Zeng, L., Zhang, Y., Wahner, A., and Zhang, Y.: Radical chemistry at a rural site (Wangdu) in the North China Plain: observation and model calculations of $\mathrm{OH}, \mathrm{HO}_{2}$ and $\mathrm{RO}_{2}$ radicals, Atmos. Chem. Phys., 17, 663-690, https://doi.org/10.5194/acp17-663-2017, 2017.

Tan, Z., Rohrer, F., Lu, K., Ma, X., Bohn, B., Broch, S., Dong, H., Fuchs, H., Gkatzelis, G. I., Hofzumahaus, A., Holland, F., Li, X., Liu, Y., Liu, Y., Novelli, A., Shao, M., Wang, H., Wu, Y., Zeng, L., Hu, M., Kiendler-Scharr, A., Wahner, A., and Zhang, Y.: Wintertime photochemistry in Beijing: observations of $\mathrm{RO}_{x}$ radical concentrations in the North China Plain during the BEST-ONE campaign, Atmos. Chem. Phys., 18, 1239112411, https://doi.org/10.5194/acp-18-12391-2018, 2018. 
Tong, S., Hou, S., Zhang, Y., Chu, B., Liu, Y., He, H., Zhao, P., and Ge, M.: Comparisons of measured nitrous acid (HONO) concentrations in a pollution period at urban and suburban Beijing, in autumn of 2014, Sci. China Chem., 58, 1393-1402, https://doi.org/10.1007/s11426-015-5454-2, 2015.

Underwood, G., Song, C., Phadnis, M., Carmichael, G., and Grassian, V.: Heterogeneous reactions of $\mathrm{NO}_{2}$ and $\mathrm{HNO}_{3}$ on oxides and mineral dust: A combined laboratory and modeling study, J. Geophys. Res.-Atmos., 106, 18055-18066, 2001.

VandenBoer, T., Markovic, M., Sanders, J., Ren, X., Pusede, S., Browne, E., Cohen, R., Zhang, L., Thomas, J., and Brune, W.: Evidence for a nitrous acid (HONO) reservoir at the ground surface in Bakersfield, CA, during CalNex 2010, J. Geophys. Res.Atmos., 119, 9093-9106, 2014a.

VandenBoer, T. C., Young, C. J., Talukdar, R. K., Markovic, M. Z., Brown, S. S., Roberts, J. M., and Murphy, J. G.: Nocturnal loss and daytime source of nitrous acid through reactive uptake and displacement, Nat. Geosci., 8, 55-60, https://doi.org/10.1038/ngeo2298, 2014b.

Villena, G., Kleffmann, J., Kurtenbach, R., Wiesen, P., Lissi, E., Rubio, M. A., Croxatto, G., and Rappenglück, B.: Vertical gradients of $\mathrm{HONO}, \mathrm{NO}_{x}$ and $\mathrm{O}_{3}$ in Santiago de Chile, Atmos. Environ., 45, 3867-3873, https://doi.org/10.1016/j.atmosenv.2011.01.073, 2011a.

Villena, G., Wiesen, P., Cantrell, C. A., Flocke, F., Fried, A., Hall, S. R., Hornbrook, R. S., Knapp, D., Kosciuch, E., Mauldin, R. L., McGrath, J. A., Montzka, D., Richter, D., Ullmann, K., Walega, J., Weibring, P., Weinheimer, A., Staebler, R. M., Liao, J., Huey, L. G., and Kleffmann, J.: Nitrous acid (HONO) during polar spring in Barrow, Alaska: A net source of OH radicals?, J. Geophys. Res., 116, D00R07, https://doi.org/10.1029/2011jd016643, $2011 b$.

Wang, G., Zhang, R., Gomez, M. E., Yang, L., Levy Zamora, M., Hu, M., Lin, Y., Peng, J., Guo, S., Meng, J., Li, J., Cheng, C., Hu, T., Ren, Y., Wang, Y., Gao, J., Cao, J., An, Z., Zhou, W., Li, G., Wang, J., Tian, P., Marrero-Ortiz, W., Secrest, J., Du, Z., Zheng, J., Shang, D., Zeng, L., Shao, M., Wang, W., Huang, Y., Wang, Y., Zhu, Y., Li, Y., Hu, J., Pan, B., Cai, L., Cheng, Y., Ji, Y., Zhang, F., Rosenfeld, D., Liss, P. S., Duce, R. A., Kolb, C. E., and Molina, M. J.: Persistent sulfate formation from London Fog to Chinese haze, P. Natl. Acad. Sci. USA, 113, 13630-13635, https://doi.org/10.1073/pnas.1616540113, 2016.

Wang, J., Zhang, X., Guo, J., Wang, Z., and Zhang, M.: Observation of nitrous acid (HONO) in Beijing, China: Seasonal variation, nocturnal formation and daytime budget, Sci. Total Environ., 587, 350-359, https://doi.org/10.1016/j.scitotenv.2017.02.159, 2017.

Wang, S.: Atmospheric observations of enhanced $\mathrm{NO}_{2}-\mathrm{HONO}$ conversion on mineral dust particles, Geophys. Res. Lett., 30, 1595, https://doi.org/10.1029/2003g1017014, 2003

Wang, S., Zhou, R., Zhao, H., Wang, Z., Chen, L., and Zhou, B.: Long-term observation of atmospheric nitrous acid (HONO) and its implication to local $\mathrm{NO}_{2}$ levels in Shanghai, China, Atmos. Environ., 77, 718-724, https://doi.org/10.1016/j.atmosenv.2013.05.071, 2013.

Wentzell, J. J. B., Schiller, C. L., and Harris, G. W.: Measurements of HONO during BAQS-Met, Atmos. Chem. Phys., 10, 1228512293, https://doi.org/10.5194/acp-10-12285-2010, 2010.
Wong, K. W., Oh, H.-J., Lefer, B. L., Rappenglück, B., and Stutz, J.: Vertical profiles of nitrous acid in the nocturnal urban atmosphere of Houston, TX, Atmos. Chem. Phys., 11, 3595-3609, https://doi.org/10.5194/acp-11-3595-2011, 2011.

Xie, Y., Ding, A., Nie, W., Mao, H., Qi, X., Huang, X., Xu, Z., Kerminen, V.-M., Petäjä, T., Chi, X., Virkkula, A., Boy, M., Xue, L., Guo, J., Sun, J., Yang, X., Kulmala, M., and $\mathrm{Fu}, \mathrm{C}$. : Enhanced sulfate formation by nitrogen dioxide: Implications from in situ observations at the SORPES station, J. Geophys. Res.-Atmos., 120, 12679-12694, https://doi.org/10.1002/2015jd023607, 2015.

Xu, Z., Wang, T., Xue, L. K., Louie, P. K. K., Luk, C. W. Y., Gao, J., Wang, S. L., Chai, F. H., and Wang, W. X.: Evaluating the uncertainties of thermal catalytic conversion in measuring atmospheric nitrogen dioxide at four differently polluted sites in China, Atmos. Environ., 76, 221-226, https://doi.org/10.1016/j.atmosenv.2012.09.043, 2013.

Xu, Z., Wang, T., Wu, J., Xue, L., Chan, J., Zha, Q., Zhou, S., Louie, P. K. K., and Luk, C. W. Y.: Nitrous acid (HONO) in a polluted subtropical atmosphere: Seasonal variability, direct vehicle emissions and heterogeneous production at ground surface, Atmos. Environ., 106, 100-109, https://doi.org/10.1016/j.atmosenv.2015.01.061, 2015.

Xu, Z., Huang, X., Nie, W., Chi, X., Xu, Z., Zheng, L., Sun, P., and Ding, A.: Influence of synoptic condition and holiday effects on VOCs and ozone production in the Yangtze River Delta region, China, Atmos. Environ., 168, 112-124, https://doi.org/10.1016/j.atmosenv.2017.08.035, 2017.

Xu, Z., Huang, X., Nie, W., Shen, Y., Zheng, L., Xie, Y., Wang, T., Ding, K., Liu, L., Zhou, D., Qi, X., and Ding, A.: Impact of Biomass Burning and Vertical Mixing of Residual-Layer Aged Plumes on Ozone in the Yangtze River Delta, China: A Tethered-Balloon Measurement and Modeling Study of a Multiday Ozone Episode, J. Geophys. Res.-Atmos., 123, 11786711803, https://doi.org/10.1029/2018jd028994, 2018.

Yabushita, A., Enami, S., Sakamoto, Y., Kawasaki, M., Hoffmann, M. R., and Colussi, A. J.: Anion-Catalyzed Dissolution of $\mathrm{NO}_{2}$ on Aqueous Microdroplets, J. Phys. Chem. A, 113, 4844-4848, https://doi.org/10.1021/jp900685f, 2009.

Ye, C., Zhou, X., Pu, D., Stutz, J., Festa, J., Spolaor, M., Tsai, C., Cantrell, C., Mauldin, R. L., 3rd, Campos, T., Weinheimer, A., Hornbrook, R. S., Apel, E. C., Guenther, A., Kaser, L., Yuan, B., Karl, T., Haggerty, J., Hall, S., Ullmann, K., Smith, J. N., Ortega, J., and Knote, C.: Rapid cycling of reactive nitrogen in the marine boundary layer, Nature, 532, 489-491, https://doi.org/10.1038/nature17195, 2016.

Ye, C., Zhang, N., Gao, H., and Zhou, X.: Photolysis of Particulate Nitrate as a Source of HONO and NOx, Environ. Sci. Technol., 51, 6849-6856, https://doi.org/10.1021/acs.est.7b00387, 2017.

Yu, Y., Galle, B., Panday, A., Hodson, E., Prinn, R., and Wang, S.: Observations of high rates of $\mathrm{NO}_{2}-\mathrm{HONO}$ conversion in the nocturnal atmospheric boundary layer in Kathmandu, Nepal, Atmos. Chem. Phys., 9, 6401-6415, https://doi.org/10.5194/acp-9-64012009, 2009.

Zhou, L., Wang, W., Hou, S., Tong, S., and Ge, M.: Heterogeneous uptake of nitrogen dioxide on Chinese mineral dust, J. Environ. Sci. (China), 38, 110-118, https://doi.org/10.1016/j.jes.2015.05.017, 2015. 
Zhou, X., Civerolo, K., Dai, H., Huang, G., Schwab, J., and Demerjian, K.: Summertime nitrous acid chemistry in the atmospheric boundary layer at a rural site in New York State, J. Geophys. Res.-Atmos., 107, ACH 13-11-ACH 13-11, https://doi.org/10.1029/2001jd001539, 2002.

Zhou, X., Gao, H., He, Y., Huang, G., Bertman, S. B., Civerolo, K., and Schwab, J.: Nitric acid photolysis on surfaces in low- $\mathrm{NO}_{\mathrm{X}}$ environments: Significant atmospheric implications, Geophys. Res. Lett., 30, 2217, https://doi.org/10.1029/2003gl018620, 2003.
Zhou, X., Zhang, N., TerAvest, M., Tang, D., Hou, J., Bertman, S., Alaghmand, M., Shepson, P. B., Carroll, M. A., Griffith, S., Dusanter, S., and Stevens, P. S.: Nitric acid photolysis on forest canopy surface as a source for tropospheric nitrous acid, Nat. Geosci., 4, 440-443, https://doi.org/10.1038/ngeo1164, 2011. 